\title{
Downstream changes of meandering styles in the lower reaches of the River Vecht, the Netherlands
}

\section{H.P. Wolfert ${ }^{\star}$ \& G.J. Maas}

Alterra, Wageningen University and Research Centre, P.0. Box 47, 6700 AA Wageningen, the Netherlands.

* Corresponding author. Email: henk.wolfert@wur.nl

Manuscript received: December 2004; accepted: August 2007

\begin{abstract}
The morphodynamics of the lower River Vecht, the Netherlands, and the influence of geomorphological setting and bank composition on meander migration were studied by means of reconstructing the pre-channelization landform configuration on a scale of $1: 25,000$, using historical maps from 1720, 1850 and 1890 A.D. and other data.

A downstream sequence of reaches was observed, each with a typical fluvial style and channel migration rate: (a) a narrow meander belt and a highly sinuous channel with intermediate migration rate, in the middle of an extensive floodbasin; (b) a wide meander belt and high rates of lateral channel migration, especially where large meanders impinged upon valley bluffs, as part of an incised setting; (c) a low sinuosity, embanked channel with low rates of downstream migration because of confinement by dikes, occurring in an inland delta with sandy sediments.

Local variation in meander migration rates was observed within reach B. This was caused by the spatial variability of bank resistance as reflected by the width-depth ratio of the channel and the silt-clay ratios of deposits. River banks are: 1) very erodible when consisting of channel deposits, aeolian dune deposits or when coarse fluvio-periglacial deposits occur at their base; 2) erodible when dominated by overbank deposits or aeolian sand sheet deposits; 3) resistant when a plaggen-layer is exposed; and 4) very resistant when dominated by floodbasin deposits.

These implications of meander variability enable to assess the effects of the rehabilitation of the meandering process.
\end{abstract}

Keywords: channel migration, floodplain geomorphology, fluvial sediments, river rehabilitation

\section{Introduction}

Rehabilitating fluvial processes in channelized river systems has become an important theme in water management during the 1990s (Van de Kraats, 1994; Brookes \& Shields, 1996; Hansen et al., 1998). One of the processes involved is meandering (e.g. Glitz, 1983; Brookes, 1987; Vivash et al., 1998; Wolfert, 2001). Meandering is considered important to achieve 1) renewal of habitats for in-stream fauna as well as riparian vegetation; 2) a longer retention time for water in the fluvial system; and 3) an increased recreational amenity of the fluvial landscape. Rehabilitation of the meandering process in straightened channels was initially restricted to small streams in Europe and Northern America. However, the possibilities for meander rehabilitation in medium-sized rivers are increasingly being explored (e.g. Rasmussen, 1999; Detering, 2000; Duursema
2004). In these river systems re-meandering possibly implies erosion of floodplain lands, while built-up area and infrastructure have expanded since channelization. In rehabilitation planning, therefore, one has to assess how the future effects of meandering will vary along the river, in order to determine where measures will be feasible and most cost-effective.

Single-thread meandering rivers are generally associated with intermediate values of stream power and intermediate textured floodplain sediments (Leopold \& Wolman, 1957; Knighton, 1984; Nanson \& Croke, 1992; Van den Berg, 1995). Terrain and sedimentary variability are mentioned as primary controls on the downstream changes in long-term rates of lateral channel migration of meandering rivers. Point-bar accretion was described to decrease dramatically in the lower reaches of the Mississippi River as the river scoured into coarse alluvial sands, Pleistocene clays and prodelta clays successively (Kolb, 
1963). A sequence of truly free, confined free, restricted and fixed meanders was observed to be strongly influenced by the distribution of thick, fine-grained cohesive floodplain deposits along the River Teshio (Ikeda, 1989). In certain reaches, crossings with older meander belts increased lateral change of the distributaries of the Rhine-Meuse deltaic area (Berendsen, 1982). The occurrence of clay plugs in sandy alluvial sediments of the Mississippi River has been shown to hamper channel migration rates (Hudson \& Kesel, 2000).

However, it has long been agreed that the resistance of river bank materials is under-exposed in the study of channel patterns (e.g. Knighton, 1984; Bull, 1991; Parker, 1998) and the lack of field data still prevents the identification of a predictor of lateral channel migration. Aim of this study, therefore, was 1) to document the relationship between geomorphological setting and meandering styles; 2) to determine the influence of sedimentary variability on channel migration rates; and 3) to advocate the use of this type of geomorphological information in the selection process of areas suitable for meander rehabilitation. In this paper a case study is presented on the lower River Vecht in the eastern part of the Netherlands (Fig. 1), which was relatively unaffected by major human disturbance prior to channelization in the early 1890s. The floodplain geomorphology, historical maps and 19th century engineering data provided an opportunity to investigate the spatial variability of channel pattern change in space and time.

\section{Materials and methods}

\section{The study area}

The River Vecht is a $167 \mathrm{~km}$ long river which drains an area of $3785 \mathrm{~km}^{2}$ (Fig. 1). Its source is in the hills of Lower Saxony, Germany, at approximately $110 \mathrm{~m}$ above sea level. The river debouches into Lake IJssel (the former Zuiderzee) in the Netherlands. In the eastern part, the drainage basin has an undulating topography, formed in Cretaceous limestones, Tertiary clays and Pleistocene tills. In the western part, flat lowlands occur, underlain by Weichselian fluvio-periglacial sands, locally covered by aeolian sands of Weichselian (coversands) or Holocene age. Near its mouth the river encounters a Holocene environment with fluvial clays and coastal peat. Mean annual precipitation varies from $700-825 \mathrm{~mm}$, and evapotranspiration approximates $525 \mathrm{~mm}$ (Meinardi et al., 1998). The discharge regime is characterised by a relatively quick response during periods of high precipitation in winter, and an almost absence of flow during summer. Peak discharges occurring once in two years, approximating bankfull discharge, amount $182 \mathrm{~m}^{3} \mathrm{~s}^{-1}$ near the Dutch-German border at present.

Downstream of the village of Dalfsen (Fig. 1), dikes were constructed along the river since the 14th century. The Dutch part of river was channelized during the periods 1896 - 1914 and 1932 - 1957, followed by the German part during the period

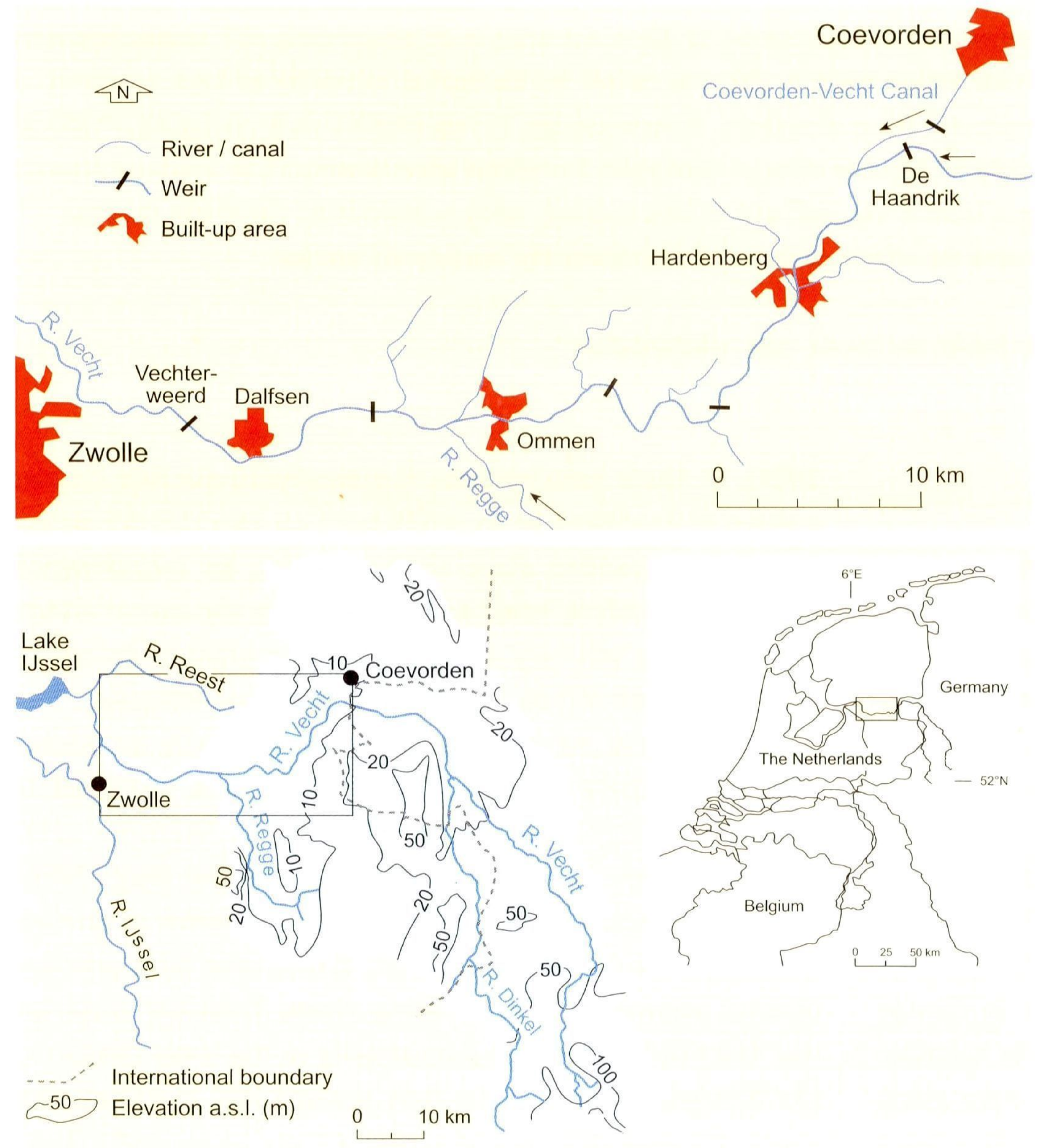

Fig. 1. Location of the River Vecht and study area. 
1952 - 1960. In the Netherlands, 69 meanders were cut off, reducing the original length of the lower River Vecht from 90 to $60 \mathrm{~km}$. To prevent degradation of the channel and an associated lowering of groundwater levels in the surrounding region, as well as to serve navigation in canals connected to the river near De Haandrik (Fig. 1), 7 weirs were constructed of which 6 remain today. Besides, revetments were installed all along the river banks. Parts of the floodplain have been levelled for agricultural purposes, but much of the original floodplain topography still exists.

Downstream changes in discharge and valley slope, which determine stream power, and bank composition may have influenced lateral channel migration of the pre-channelized River Vecht. However, the 0.00014 valley slope of the entire lowland River Vecht was rather uniform within the study area (Fig. 2a), as could be derived from 1848 stage data (Staring \& Stieltjes, 1848). The discharge of the River Vecht increases in downstream direction, mainly due to confluences with the Coevorden-Vecht Canal (named Coevordense Vecht before channelization) and the River Regge (Fig. 2b). These observations justify the assumption that spatial differences in fluvial style and lateral channel migration that do not coincide with these two points of confluence are likely to be caused by differences in geomorphological setting or bank composition.

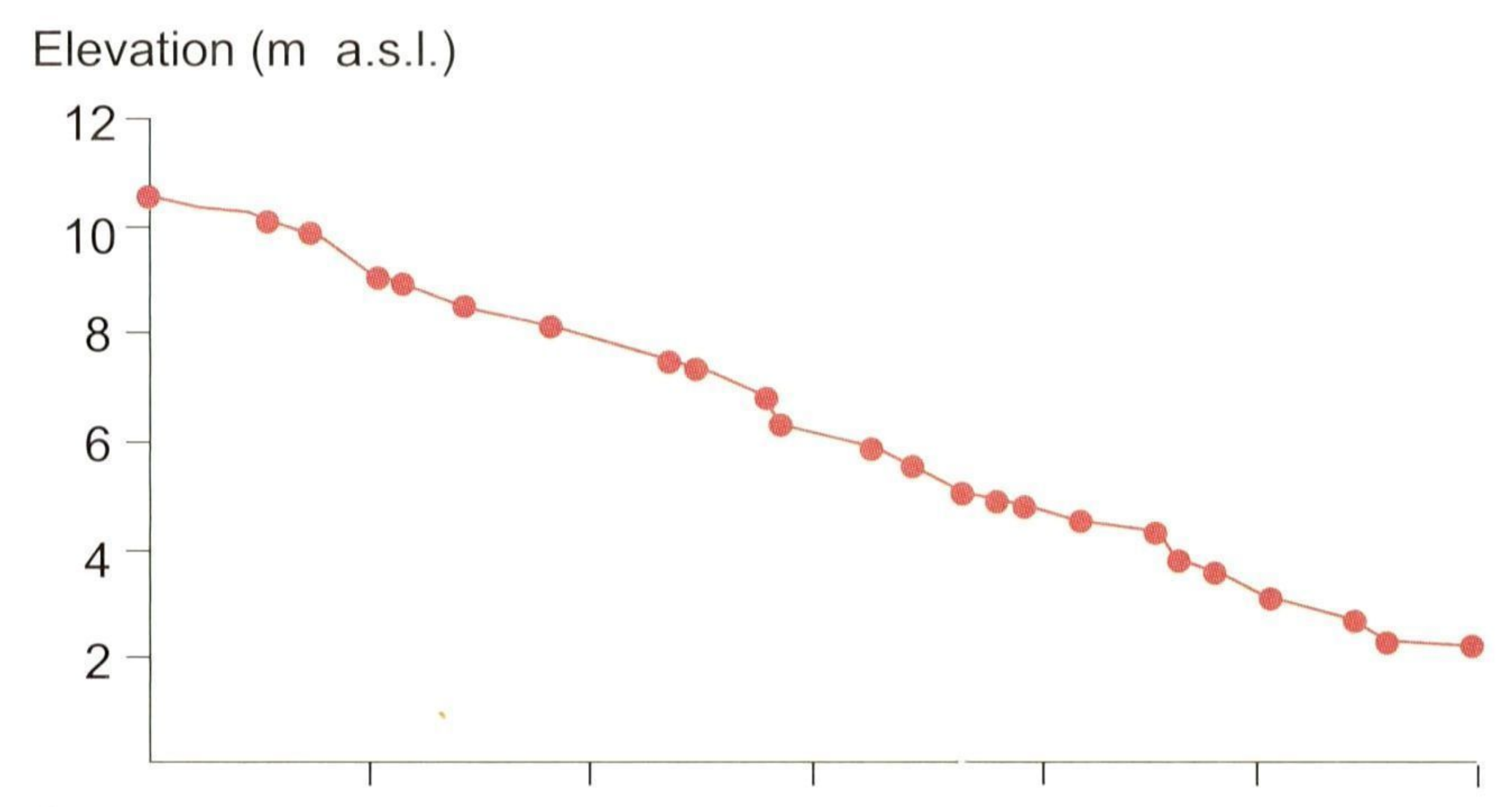

Drainage basin area $(\%)$

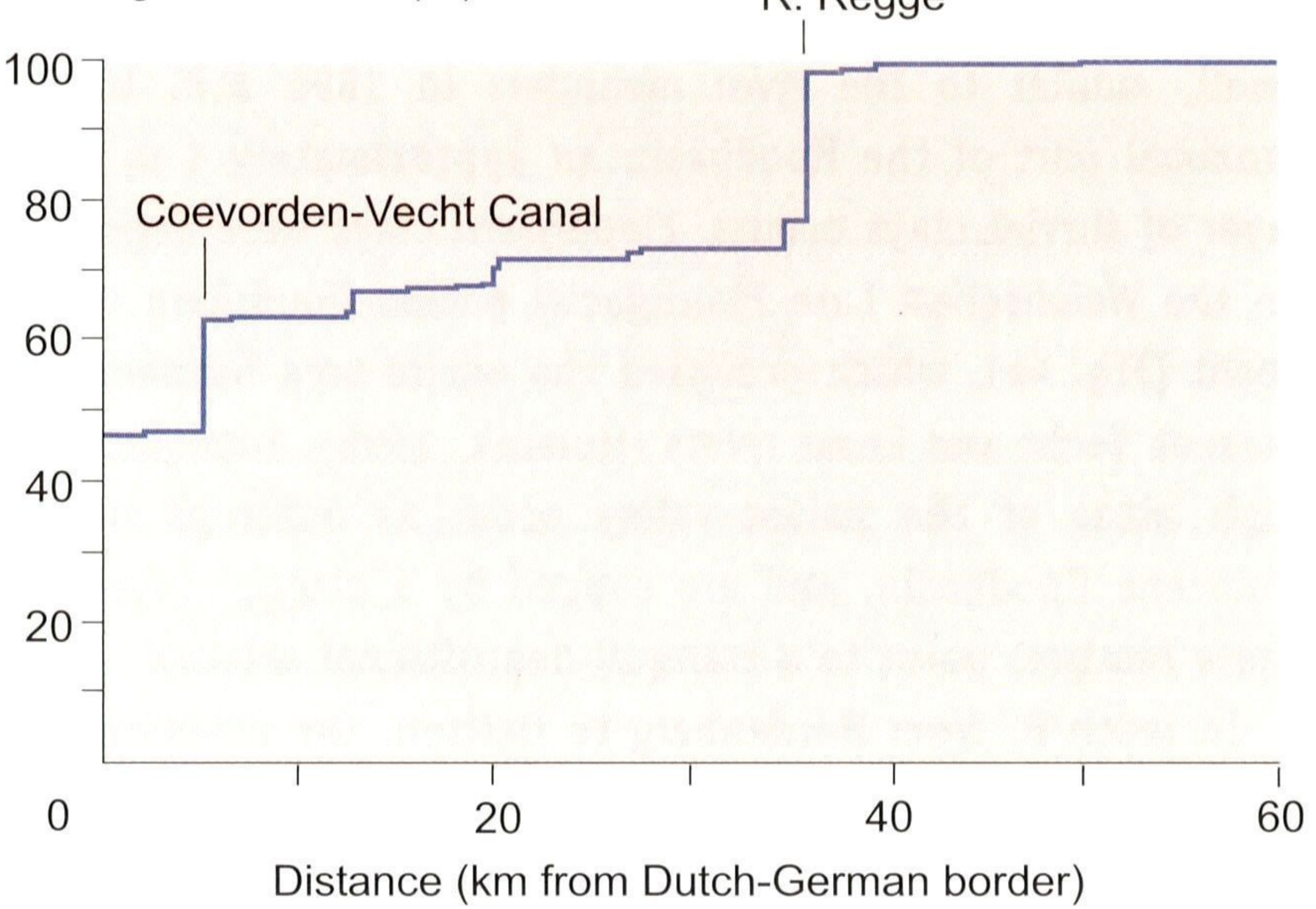

b.

Fig. 2. Changes in a. valley slope; and b. discharge along the lower River Vecht

\section{Geomorphological survey}

The pre-channelization geomorphology of the study area (i.e. occurring in 1890 A.D.) was reconstructed and mapped on a scale of $1: 25,000$. Mapping was based on information provided by available maps on various scales on geomorphology, soils, and topography, and on aerial photographs from the period 1944 - 1951 (see for a detailed list Wolfert et al., 1996). Classification of morphological units of fluvial origin was based on commonly distinguished landforms and deposits of sand-bed alluvial rivers (e.g. Leopold et al., 1964; Reineck \& Singh, 1980). Terrains with a plaggen-layer were mapped as open field. Plaggen-soils are the result of many centuries of manuring and occur widespread in the Vecht drainage basin on various types of arable land, especially those at relatively high elevation (Pape, 1970). The plaggen-layer may be as thick as $1 \mathrm{~m}$. During the mapping procedure a field check was done, aimed at a correct interpretation of information. The maps were digitised using the software package ARC/INFO (ESRI, Redlands, CA) enabling a quantitative analysis of areas.

To analyse sedimentological characteristics, three crosssections were constructed across the floodplain to a depth of a few metres below surface. Locations have been selected that are representative for different styles of meandering, as revealed by the analysis of the geomorphological map. Boring was done by hand using an Edelman auger. For each of the 36 borings, sediment texture and soil type were described following Ten Cate et al. (1995) as well as type of organic material and presence of iron concretions.

\section{Channel migration data}

Channel migration was investigated by means of studying historical maps. Four maps were selected that satisfy criteria concerning topographic, geometric and chronometric accuracy (Hooke \& Redmond, 1989; Middelkoop, 1997) and cover large areas (Fig. 3). The oldest map dates from 1720 A.D. It shows the river between the Dutch-German border and 0mmen in the Netherlands, on a scale of $1: 19,200$. Another map from this period shows the design of a military line of defence along the river from De Haandrik to Vechterweerd, on a scale of 1:7200. As both maps are made by the same cartographer P. de la Rive and depict the river in a similar way, the information on the latter map is assumed to date from 1720 too. More recent maps used were the 19th century editions of the Topographical map on a scale of $1: 50,000$, surveyed in 1850 and 1890. A comparison of the average width of the river, measured as the channel area to channel length ratio, shows that the maps differ in accuracy, the 1720 map being the least accurate (Table 1). Therefore, the river channel depicted on each map was transformed to a geometrical correct basis by comparing it with the 1890 and recent topographical maps, before digitising. 

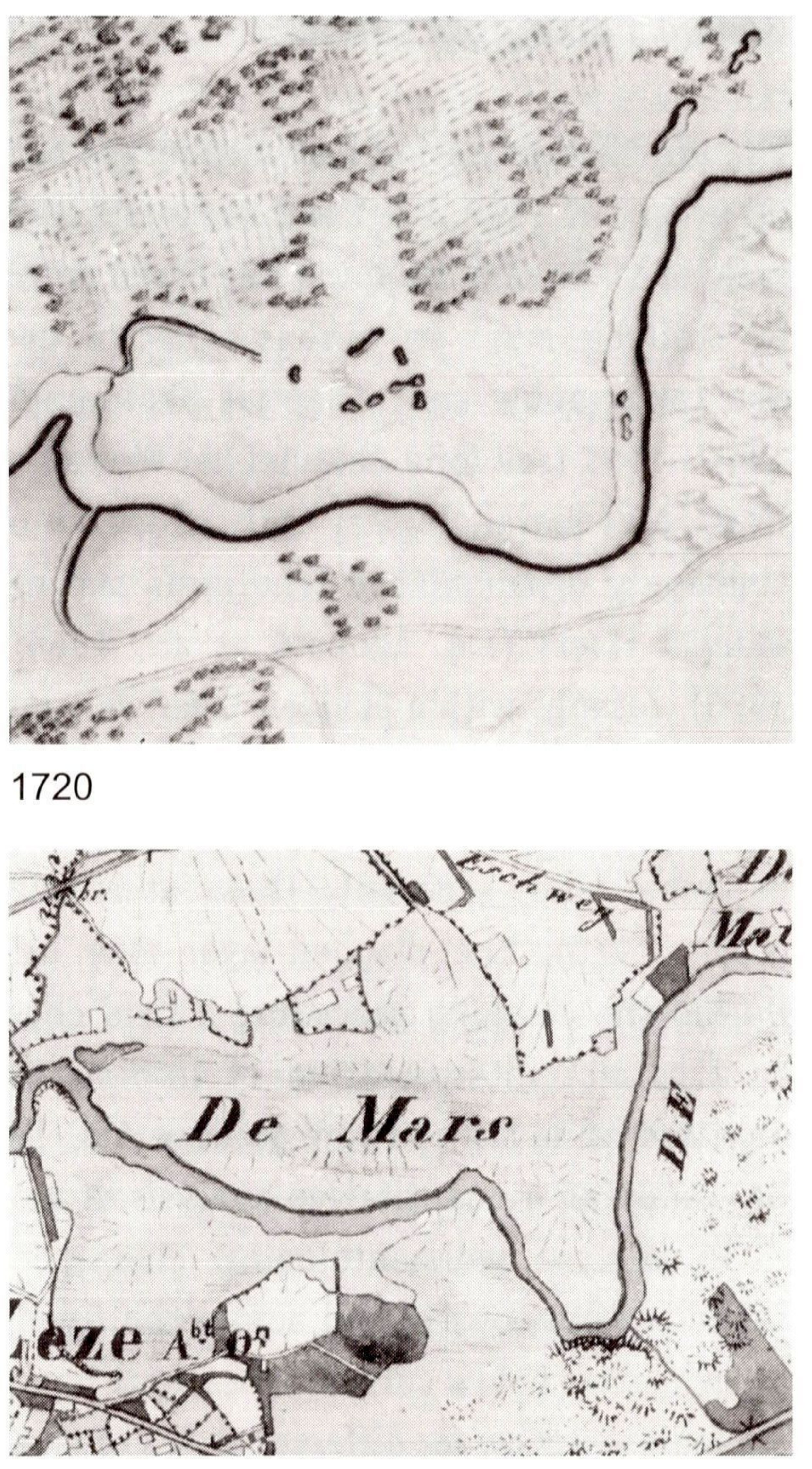

1850

Fig. 3. Fragments of the historical maps used in this study: 1720 A.D. 1850 A.D., 1890 A.D (for location see Fig. 4).

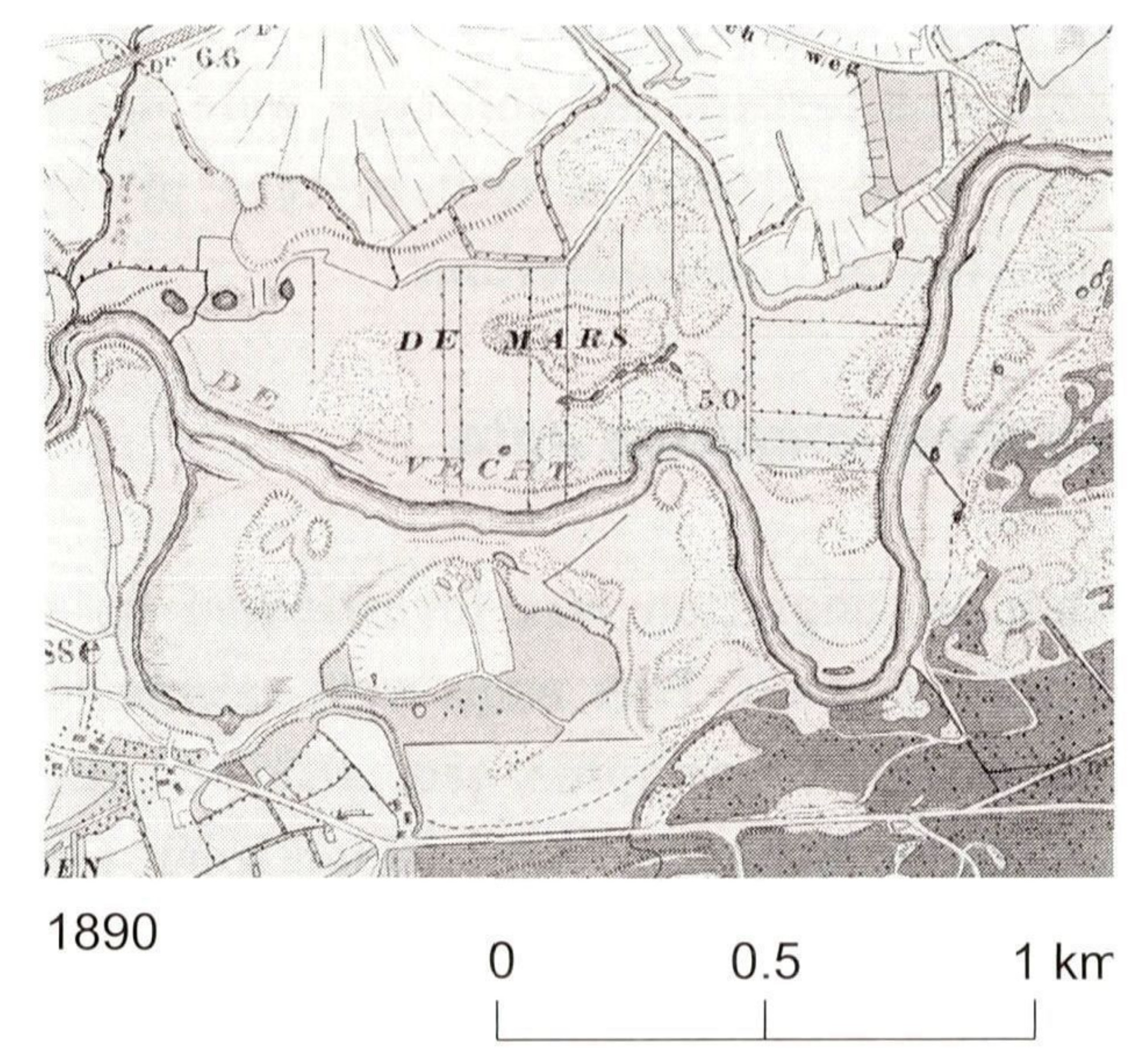

Channel-pattern characteristics were derived from the 1890 map, being geometrically the most accurate map. Meander wavelength was measured as the distance between inflection points. Reconstruction of channel migration was obtained by digital overlaying. Lateral erosion and accretion of river reaches were measured as the area between two successive positions of the river bank per unit length of river. Average channel migration rates were derived from the data on lateral erosion, because eroding banks are generally steeper than accreting banks so that their position on the historical maps is probably indicated with higher precision. Maximum bend migration was measured as the distance of migration of concave banks at the apex of the bend.
Table 1. Comparison of values of the mean width of the river channel in historical time as shown by maps and measured by Staring \& Stieltjes (1848).

\begin{tabular}{|c|c|c|c|c|}
\hline \multirow{3}{*}{$\begin{array}{l}\text { River reach } \\
\text { distinguished } \\
\text { in Fig. 4b }\end{array}$} & \multicolumn{4}{|c|}{ Width (m) } \\
\hline & \multicolumn{3}{|c|}{ Historical maps } & \multirow{2}{*}{$\begin{array}{l}\text { Measurements } \\
1848\end{array}$} \\
\hline & 1720 & 1850 & 1890 & \\
\hline A & 105.2 & 60.3 & 87.8 & 30.1 \\
\hline B1 & 117.7 & 76.3 & 65.7 & 22.3 \\
\hline B2 & 140.0 & 81.4 & 70.1 & 42.8 \\
\hline B3 & 108.4 & 83.2 & 81.7 & 49.0 \\
\hline B4 & 91.8 & 88.2 & 82.1 & 56.4 \\
\hline C & 73.2 & 64.5 & 74.2 & 93.1 \\
\hline River & 107.0 & 74.2 & 77.7 & 55.8 \\
\hline
\end{tabular}

\section{Results}

\section{River reaches and fluvial styles}

Characteristics of the landforms along the River Vecht are given in Table 2. The associated lithofacies are grouped into lithogenetic units, which can be considered architectural elements (cf. Miall, 1985). In Table 3 a lithostratigraphical classification of the architectural elements is given as well as brief lithological descriptions. Three reaches are distinguished, each with a typical fluvial style induced by differences in geomorphological setting (Fig. 4). Besides, four subreaches were distinguished within reach $B$, which was morphologically and sedimentologically not as homogeneous as the reaches $\mathrm{A}$ and $\mathrm{C}$.

Reach A, from the Dutch-German border to Hardenberg, is characterised by a relatively narrow Holocene meander belt in the middle of an extensive floodbasin (Fig. 5a; Table 4). The meander belt is mainly build-up by of natural levees. Scrollbar and swale topography is scarce, so are abandoned channels. Bend dimensions of the abandoned channels are relatively small, similar to the river meanders in 1890 A.D. In the proximal part of the floodbasin an approximately $1 \mathrm{~m}$ thick layer of fluvial clays occurs. Floodbasin clays were deposited on the Weichselian Late Pleniglacial palaeo-floodplain of the Vecht (Fig. 4a), which occupied the entire area between the present Vecht and Reest rivers (Huisink, 1998). Topographical high areas of the palaeo-valley occur as outcrops in the Holocene floodbasin, and are capped by a plaggen-layer. All these features point to a tranquil depositional setting.

In reach $\mathrm{B}$, from Hardenberg to Dalfsen, the meander belt is wider, but occurs within a valley setting (Fig. 5b). Most striking features are the many oxbow lakes enclosing relatively large areas with scroll-bar and swale topography, on top of which aeolian dunes occur frequently. Natural levees are also prominent. In contrast, floodplain flats and floodbasins 
Table 2. Geomorphological and sedimentological characteristics of landforms.

\begin{tabular}{llll}
\hline Landform & Morphology & Architectural elements & Genesis \\
\hline
\end{tabular}

Holocene fluvial landscape

River channel Sinuous channel Channel deposits

Abandoned channel (1) Abandoned, sinuous channel

Scroll bars and swales (2) Pattern of small, crescentic ridge sand elongate depressions in between

Natural levee (3)

Aeolian dunes (4)

Floodplain flat (5)

Floodbasin (6)

Dike breach pond (8)

Small depression

Weichselian periglacial and Holocene aeolian landscapes Coversand undulations / Undulating to flat terrain River terrace (9)

Open field with

Smooth and shallow undulation

plaggen-soil (10)

Aeolian dunes (11) Chaotic dune morphology
Overbank deposits or floodplain deposits on channel-fill deposits on channel deposits Overbank deposits on channel deposits

Overbank deposits on channel deposits

Aeolian deposits on overbank deposits or channel deposits Overbank deposits on channel deposits or fluvio-periglacial deposits

Floodbasin deposits on fluvio-periglacial deposits

Channel-fill deposits

Aeolian deposits on fluvio-periglacial deposits / fluvio-periglacial deposits system and deflation of deposits by wind

Plaggen-layer on aeolian dune or sand Manuring and subsequent formation sheet deposits on/or fluvio-periglacial deposits

Aeolian dune deposits on aeolian sand Deflation of coversands by wind sheet deposits

Table 3. Lithology and lithostratigraphical classification of architectural elements.

\begin{tabular}{|c|c|c|}
\hline Lithostratigraphical unit $^{1}$ & Architectural element & Lithology \\
\hline Kootwijk Member, Boxtel Formation & Aeolian dune deposits (D) & Fine sand \\
\hline \multicolumn{3}{|l|}{ (Holocene aeolian deposits) } \\
\hline Singraven Member, Boxtel Formation & Floodbasin deposits (B) & Clay, silty clay \\
\hline \multirow[t]{4}{*}{ (Holocene fluvial deposits) } & Overbank deposits (0) & $\begin{array}{l}\text { Fine sand and loamy sand; including } \\
\text { iron concretions }\end{array}$ \\
\hline & Channel-fill deposits (F) & Humic clay and clayey peat \\
\hline & Channel deposits (C) & Coarse and fine sand; occasionally with \\
\hline & & loamy layers; fining upwards \\
\hline Boxtel Formation, undifferentiated & Aeolian dune deposits (A) & Fine sand \\
\hline \multirow[t]{3}{*}{ (Weichselian periglacial deposits) } & Aeolian sand sheet deposits (S) & Loamy sand \\
\hline & Fluvio-periglacial (terrace) deposits (T) & Fine sand \\
\hline & Fluvio-periglacial (palaeo-valley) deposits (P) & Coarse and fine sand \\
\hline
\end{tabular}

1 Cf. Westerhoff et al. (2003). 


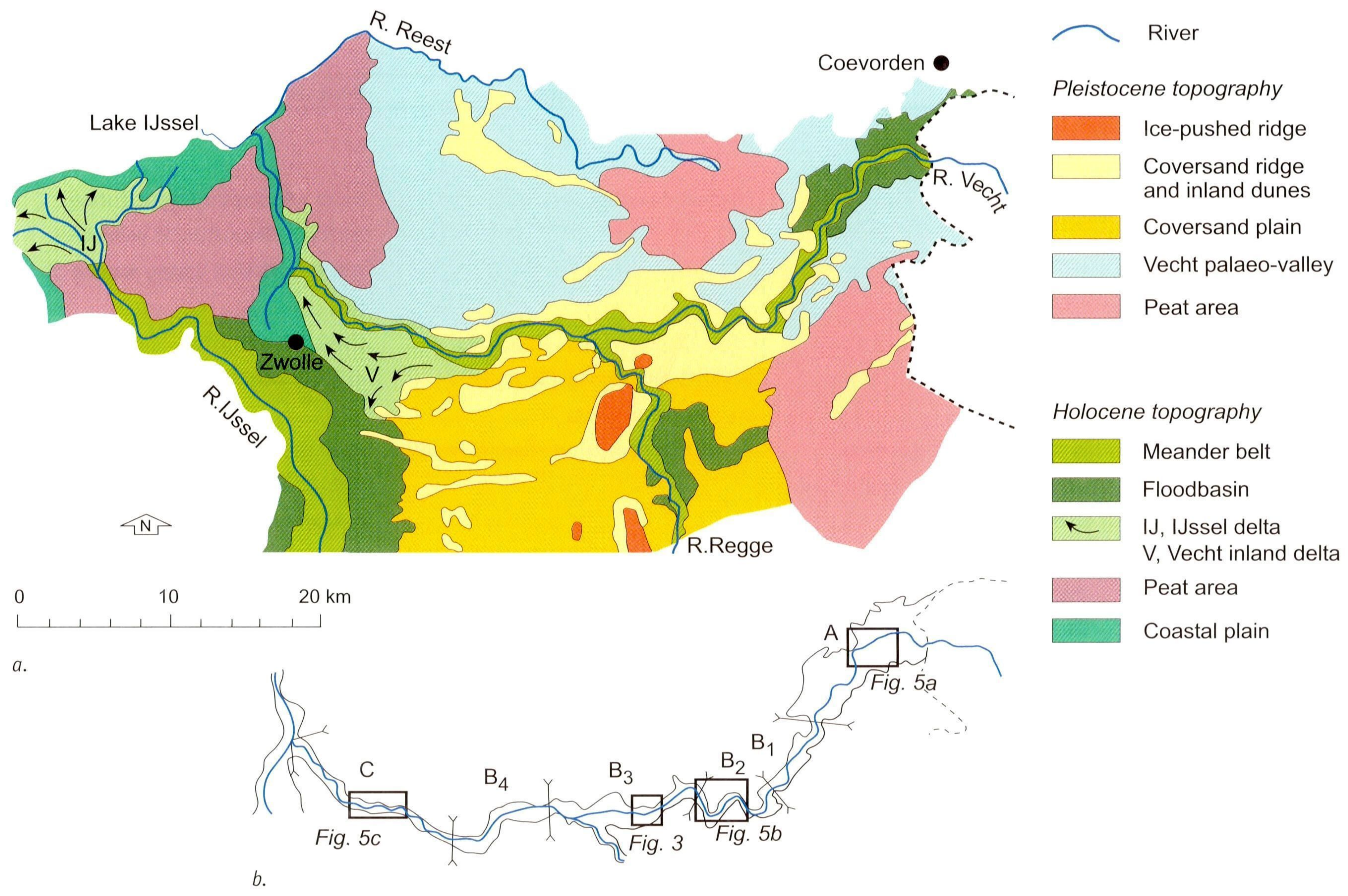

Fig. 4. Maps of a. the geomorphological setting of the lower River Vecht (based on Ente et al., 1965); and b. the river reaches distinguished.

constitute no more than half of the valley bottom area. The width of the channel belt increases in a downstream direction, while the thickness of overbank deposits and the extent of the floodbasin clays decrease (Fig. 6). The overbank deposits of floodplain flats and floodbasin clays are partly underlain by Weichselian Late Glacial fluvio-periglacial deposits (Fig. 6). At such locations the overbank deposits are rich in iron. Late Glacial fluvial terraces as well as the isolated terrace outcrops found in subreach B3 are often capped by a plaggen-layer. The river valley is bordered by conspicuous bluffs, separating its Holocene alluvial deposits from the adjacent Weichselian sandy fluvio-periglacial and aeolian deposits. Many open fields with a plaggen-layer occur along the river valley. Typical elements in subreach B2 are some large meanders that penetrate deeply into the aeolian dune areas adjacent to valley bluffs. The river abandoned its former palaeo-valley and shifted to its present valley with the onset of a warmer climate in the Weichselian Late Glacial (Huisink, 1998). River reach $B$ is interpreted as a dynamic depositional setting.

In reach C, from Dalfsen to Vechterweerd, historical channel deposits are found between the dikes. Sinuosity of the 1890 river channel was much lower compared to the other reaches (Fig. 5c). Also, a different landform configuration is observed. Natural levees occur along the upstream part of convex channel banks, while scroll bars and swales occur adjacent to the downstream part. The downstream parts of scroll bars are curved convex to the river in planform. 0xbow lakes are rare, but sloughs are characteristically connected to the river channel near the bend apex of concave banks. These features are generally related to confined rivers (Howard, 1992) where commonly downstream channel migration, instead of lateral migration occurs. Accretion was probably of the concave bank bench type (Page \& Nanson, 1982). Loamy sands dominate the deposits in this reach. This reach was embanked because of its relatively high elevation due to its position in an alluvial fanlike inland delta (Fig. 4a). This delta formed where the Vecht river system meets the Holocene fluvial and marine environments of the River IJssel and Lake IJssel, the former Zuiderzee.

\section{Lateral erosion and accretion}

The channel pattern of the River Vecht did not change dramatically in historical time: the 1720 channel pattern remained more or less unchanged until 1890 (Fig. 3). During the period 1720 - 1890, 6 meander cutoffs occurred, four of which were situated in reach $A$, one in reach $B$ and one in reach $\mathrm{C}$.

Data on lateral erosion and accretion are presented in Table 5 and Table 6. Accretion indicated by the growth of the scrollbar and swale areas indicate the renewal of floodplain lands due to lateral accretion, but only gives a rough approximation 


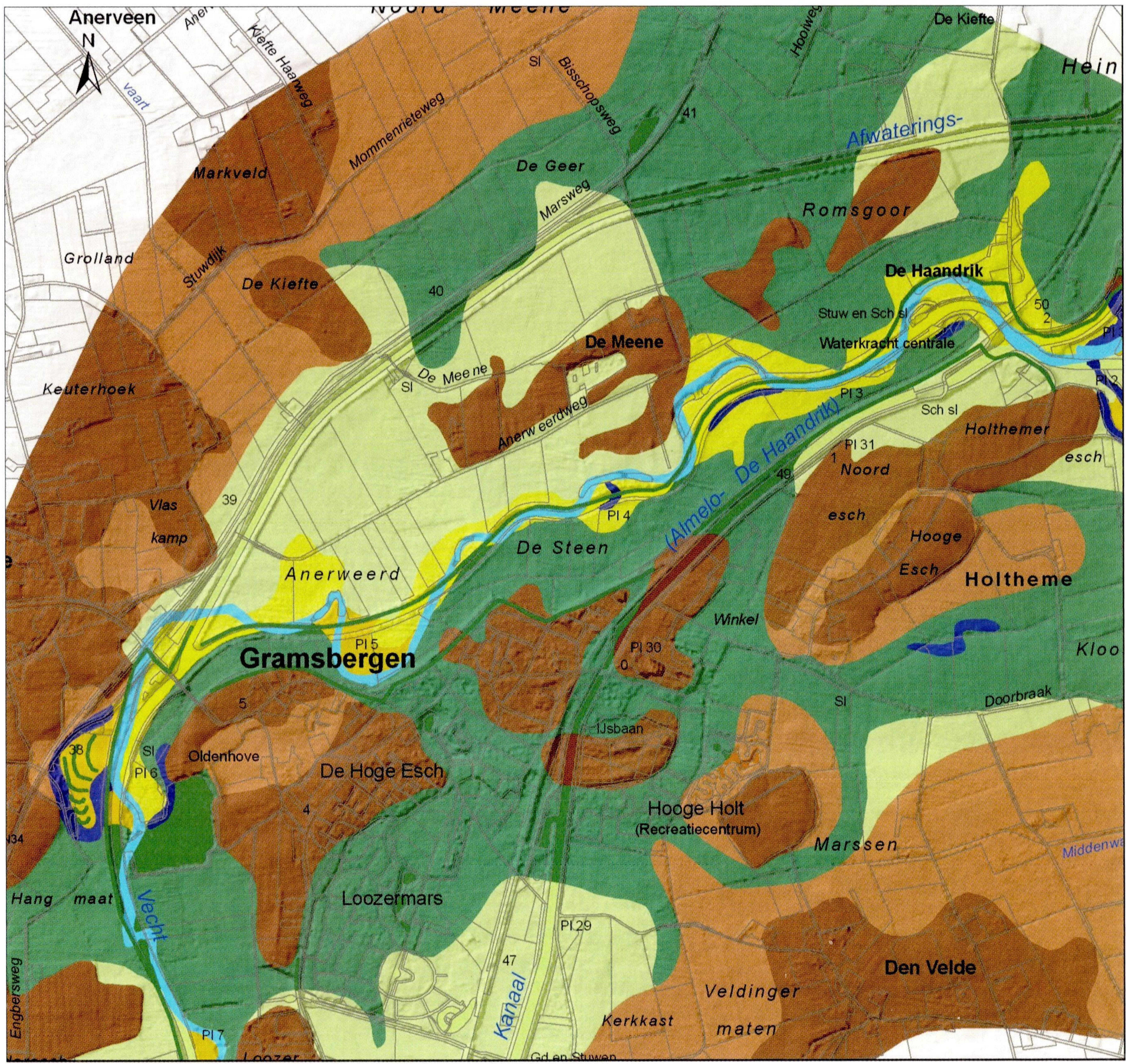

A Holocene fluvial landscape

River channel

Abandoned channel

Scroll bars and swales

Natural levee

Aeolian dunes

Floodplain flat

Floodbasin

Weichselian periglacial and Holocene aeolian landscape

0.25

0.5

Kilometers

Coversand undulations / River terrace

Open field with plaggen soil

Aeolian dunes

Vecht inland delta

Fig. 5a. Characteristic alluvial landform configuration in reach A (for location see Fig. 4).

of lateral accretion rates, as part of this topography was covered by younger overbank deposits and thus was mapped as natural levee, floodplain flat or floodbasin. Erosion indicated by differences between the position of the river on various historical maps can only approximate channel migration rates as these maps are not fully reliable. Differences in the width of the river depicted on the maps from 1720, 1850 and 1890, for instance, cause differences between measured erosion and accretion.
Nevertheless, the data show a consistent pattern, which largely reflects the differences between the reaches A, B and C. Channel migration in reach $A$ and subreach B1 was small compared to that of reach $\mathrm{B}$. This is attributed to the influence of resistant clayey floodbasin deposits which decreases in a downstream direction, due to a decrease in clay contents in the sediments. Within reach $B$, lateral erosion and accretion were largest in the subreaches B2 and B4. In these subreaches, the river flows in sandy channel deposits and often impinges 


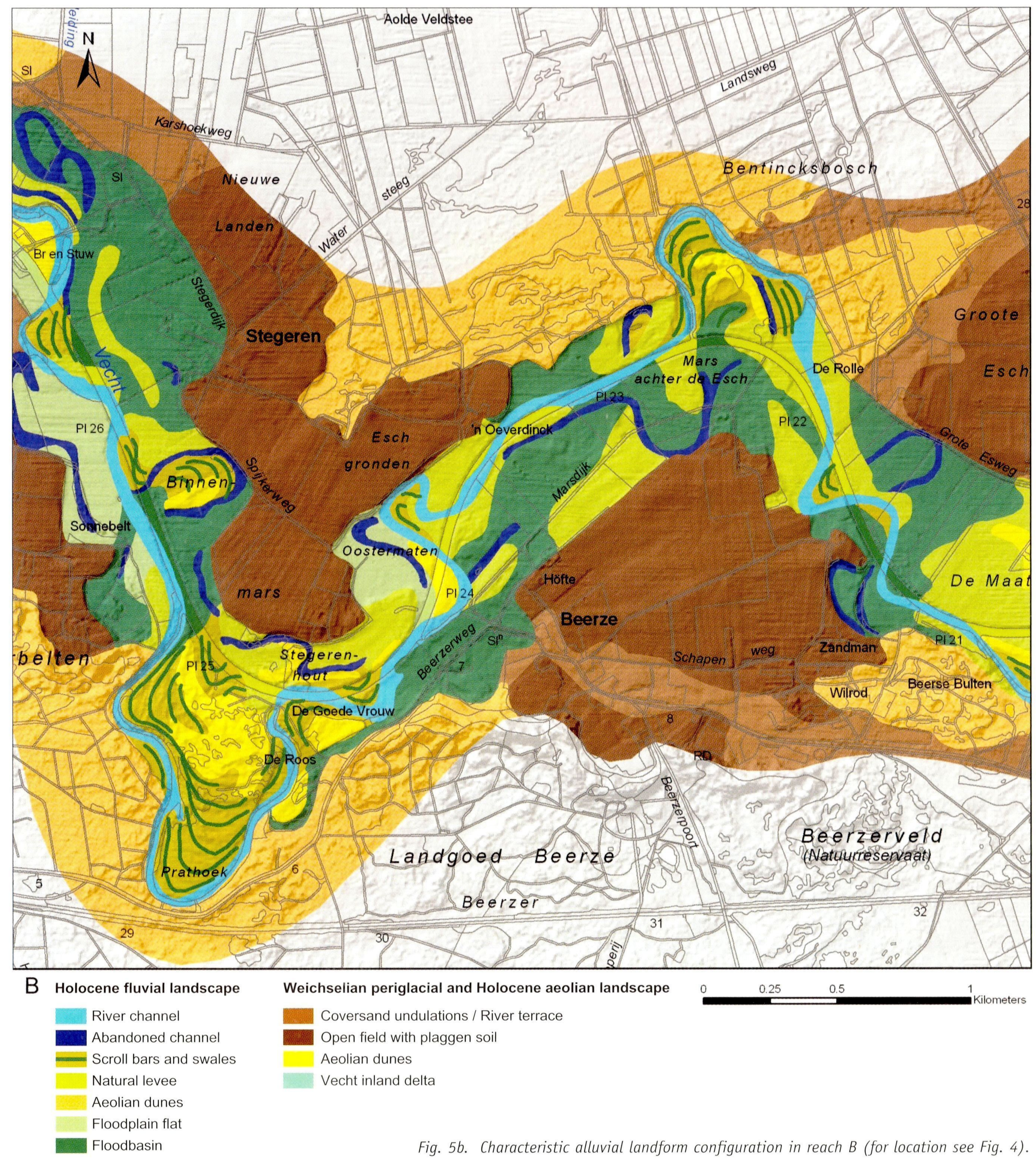

on valley bluffs consisting of sandy aeolian or fluvio-periglacial sediments (Fig. 6b and Fig. 6c). These types of bank materials are easily entrained by the water flow. Migration in reaches $\mathrm{A}$ and $B$ occurred mainly in a lateral direction. In reach $C$, the migration distance in historical time appeared to be much smaller than the area of scroll bars and swales suggests. This points to an initially dynamic river reach, in which the downstream migration of the channel eventually became hampered by the presence of dikes.
The meander wavelength of the 1890 channel for the selected river reaches is given in Figure 7 . The data reflect the differences in lateral erosion and accretion. The small wavelength in subreach B1 is very similar to the wavelength in reach $A$. Meander wavelength in reach $C$ is clearly different from the wavelenght in reaches $A$ and $B$. Within reach $B$, the ranges of values of wavelength are large in subreach B3, but are exceptionally small in subreach B4. This is related to the amount of erosion of resistant bank materials encountered by 


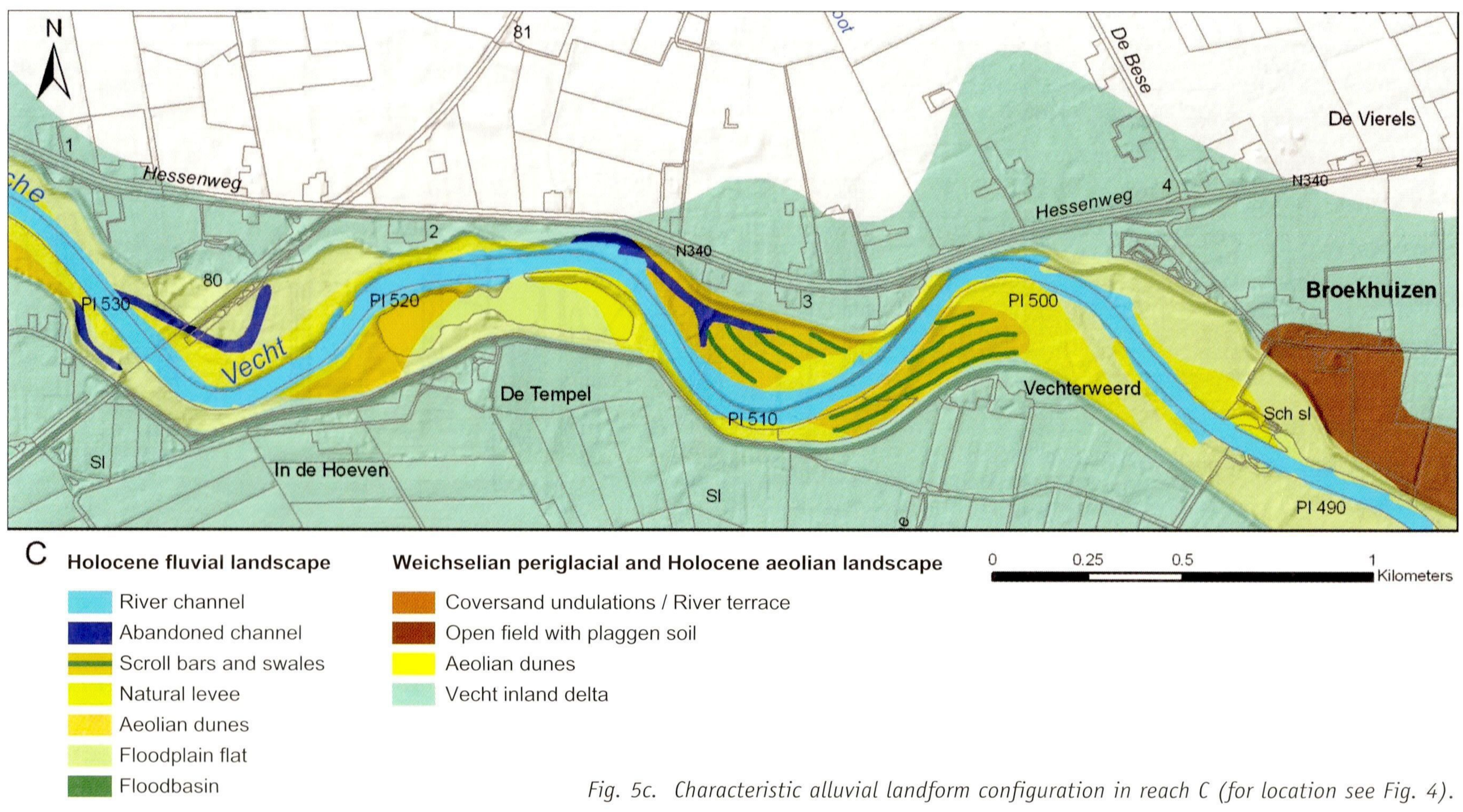

Table 4. Occurrence of fluvial landforms in river reaches and the lower River Vecht around 1890 A.D.

\begin{tabular}{|c|c|c|c|c|c|c|c|c|}
\hline \multirow{2}{*}{$\begin{array}{l}\text { River } \\
\text { reach }^{1}\end{array}$} & \multicolumn{8}{|l|}{ Landform } \\
\hline & $\begin{array}{l}\text { Abandoned } \\
\text { channel } \\
\text { (\% area) }\end{array}$ & $\begin{array}{l}\text { Scroll bars } \\
\text { and swales } \\
\text { (\% area) }\end{array}$ & $\begin{array}{l}\text { Natural } \\
\text { levee } \\
\text { (\% area) }\end{array}$ & $\begin{array}{l}\text { Aeolian } \\
\text { dunes } \\
\text { (\% area) }\end{array}$ & $\begin{array}{l}\text { Floodplain } \\
\text { flat } \\
\text { (\% area) }\end{array}$ & $\begin{array}{l}\text { Floodbasin } \\
\text { (\% area) }\end{array}$ & $\begin{array}{l}\text { Estuarine } \\
\text { basin } \\
\text { (\% area) }\end{array}$ & $\begin{array}{l}\text { Dike breach } \\
\text { pond } \\
\text { (\% area) }\end{array}$ \\
\hline A & 1.4 & 1.2 & 7.1 & 0.1 & 33.6 & 56.7 & 0.0 & 0.0 \\
\hline B1 & 9.1 & 6.0 & 20.0 & 1.4 & 0.0 & 63.4 & 0.0 & 0.0 \\
\hline B2 & 7.4 & 13.4 & 21.7 & 6.6 & 13.3 & 37.7 & 0.0 & 0.0 \\
\hline B3 & 6.1 & 14.4 & 18.6 & 9.1 & 27.8 & 24.1 & 0.0 & 0.0 \\
\hline B4 & 6.3 & 17.5 & 21.4 & 4.9 & 39.2 & 10.6 & 0.0 & 0.0 \\
\hline C & 8.4 & 15.9 & 21.6 & 0.0 & 26.9 & 4.9 & 21.1 & 1.1 \\
\hline R. Vecht & 6.5 & 11.4 & 18.4 & 3.7 & 23.5 & 32.9 & 3.5 & 0.2 \\
\hline
\end{tabular}

1 Total area: A, 1399 ha; B1, 394 ha; B2, 595 ha; B3, 859 ha; B4, 846 ha; C, 565 ha; R. Vecht, 4658 ha.

Table 5. Lateral accretion and erosion in river reaches.

\begin{tabular}{|c|c|c|c|c|c|}
\hline \multirow{3}{*}{ River reach ${ }^{1}$} & \multicolumn{3}{|l|}{ Accretion } & \multirow{2}{*}{\multicolumn{2}{|c|}{$\begin{array}{l}\text { Erosion } \\
\text { Channel migration } \\
(\mathrm{ha} / \mathrm{km})\end{array}$}} \\
\hline & $\begin{array}{l}\text { Scroll-bar and swale area } \\
(\mathrm{ha} / \mathrm{km})\end{array}$ & $\begin{array}{l}\text { Channel migration } \\
(\mathrm{ha} / \mathrm{km})\end{array}$ & & & \\
\hline & & $1720-1850$ & $1850-1890$ & $1720-1850$ & $1850-1890$ \\
\hline A & 1.20 & 9.84 & 4.19 & 5.43 & 2.61 \\
\hline B1 & 3.87 & 9.26 & 3.87 & 5.13 & 2.78 \\
\hline B2 & 8.74 & 13.18 & 4.22 & 7.96 & 3.09 \\
\hline B3 & 13.00 & 7.97 & 3.67 & 5.46 & 3.52 \\
\hline B4 & 18.27 & 10.82 & 4.67 & 10.45 & 4.06 \\
\hline C & 5.91 & 2.191 & 0.66 & 1.79 & 1.63 \\
\hline R. Vecht & 7.95 & 8.31 & 3.49 & 5.54 & 2.79 \\
\hline
\end{tabular}

1 Length of river reach, measured along valley axis: A, $12.3 \mathrm{~km} ; \mathrm{B} 1,6.1 \mathrm{~km} ; \mathrm{B} 2,9.1 \mathrm{~km} ; \mathrm{B} 3,9.5 \mathrm{~km} ; \mathrm{B} 4,8.1 \mathrm{~km} ; \mathrm{C}, 15.2 \mathrm{~km}$. 


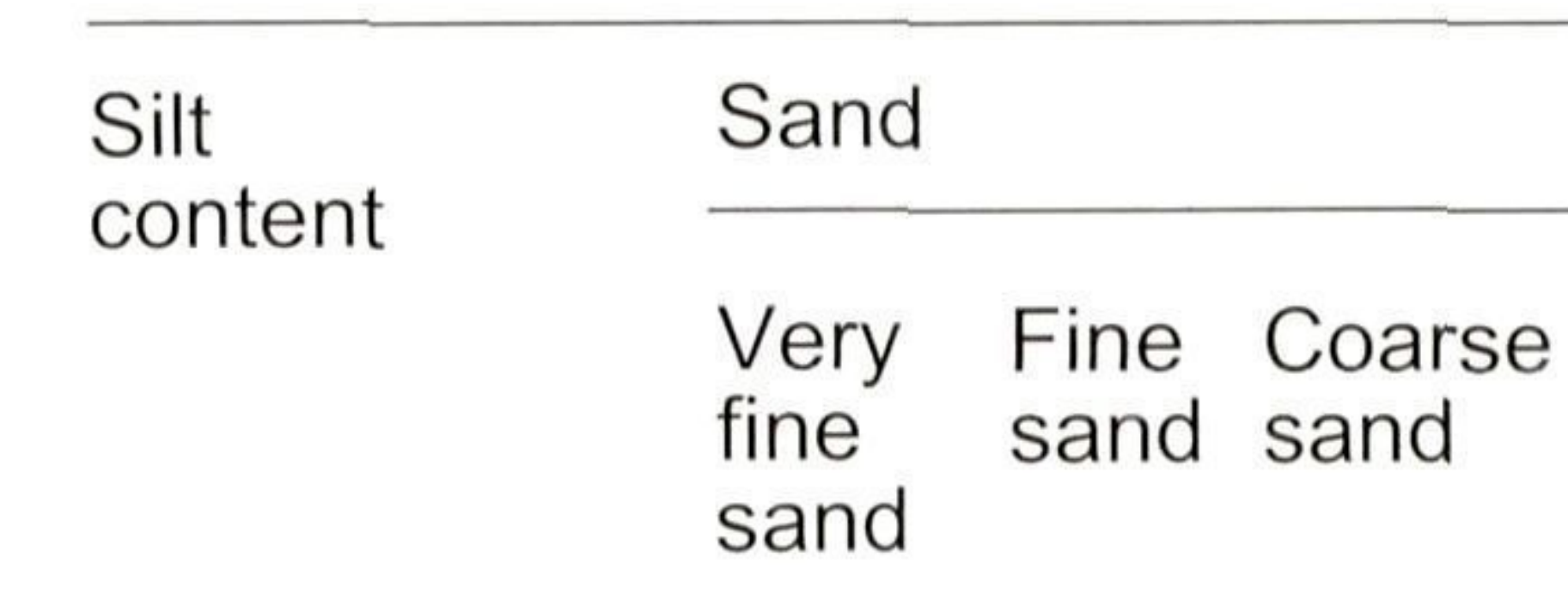

Poor in loam $\square \quad \square \quad \square$ Slightly loamy $\square \quad \square \quad \square$ Loamy ए एा] Very loamy 吥 吥

Clay; silty clay

$\equiv$ Humic clay; clayey peat

$\square$ Peat

Organic material

$\because$ Iron concretions

$\circ$ Organic debris
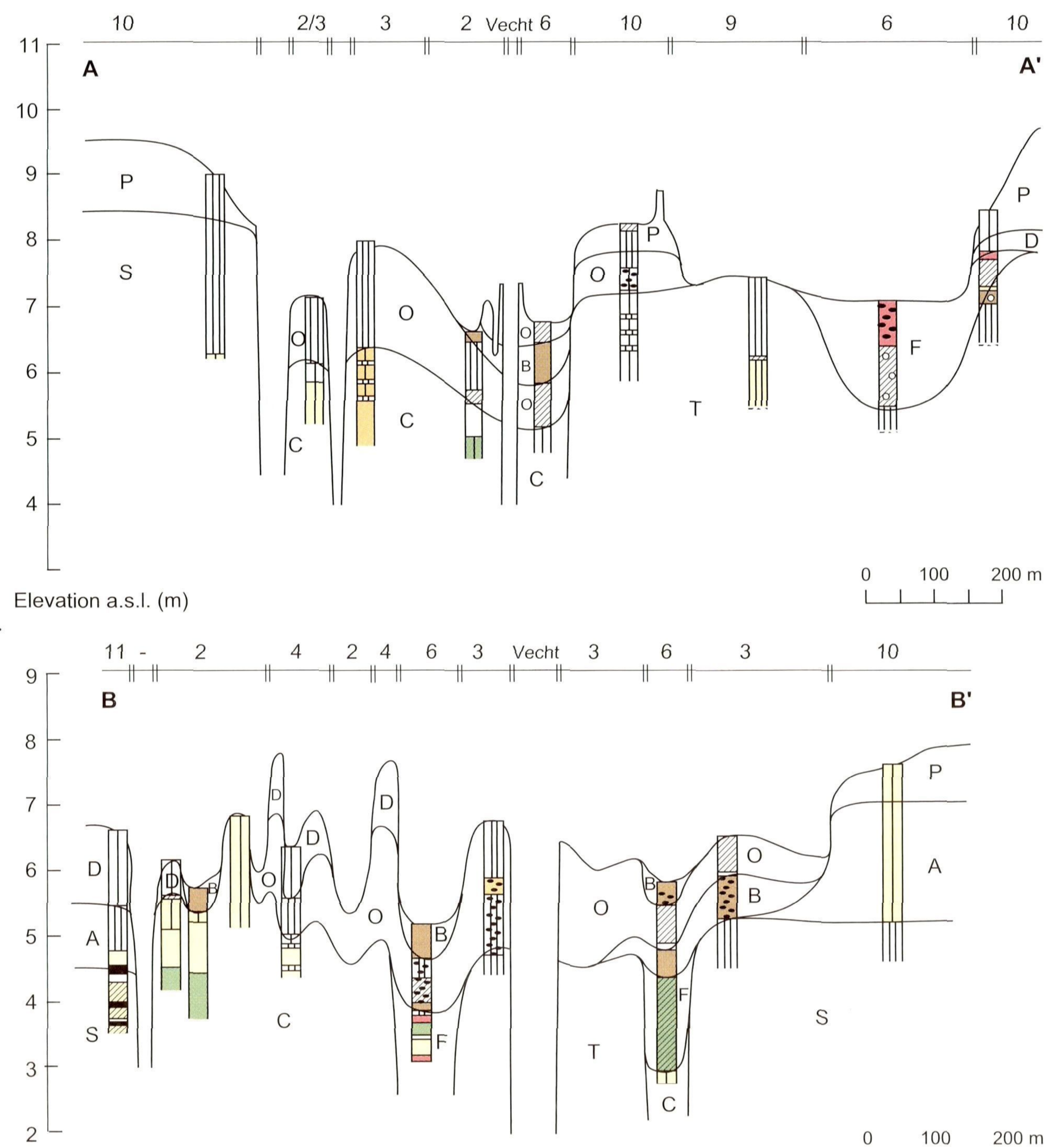
$b$.

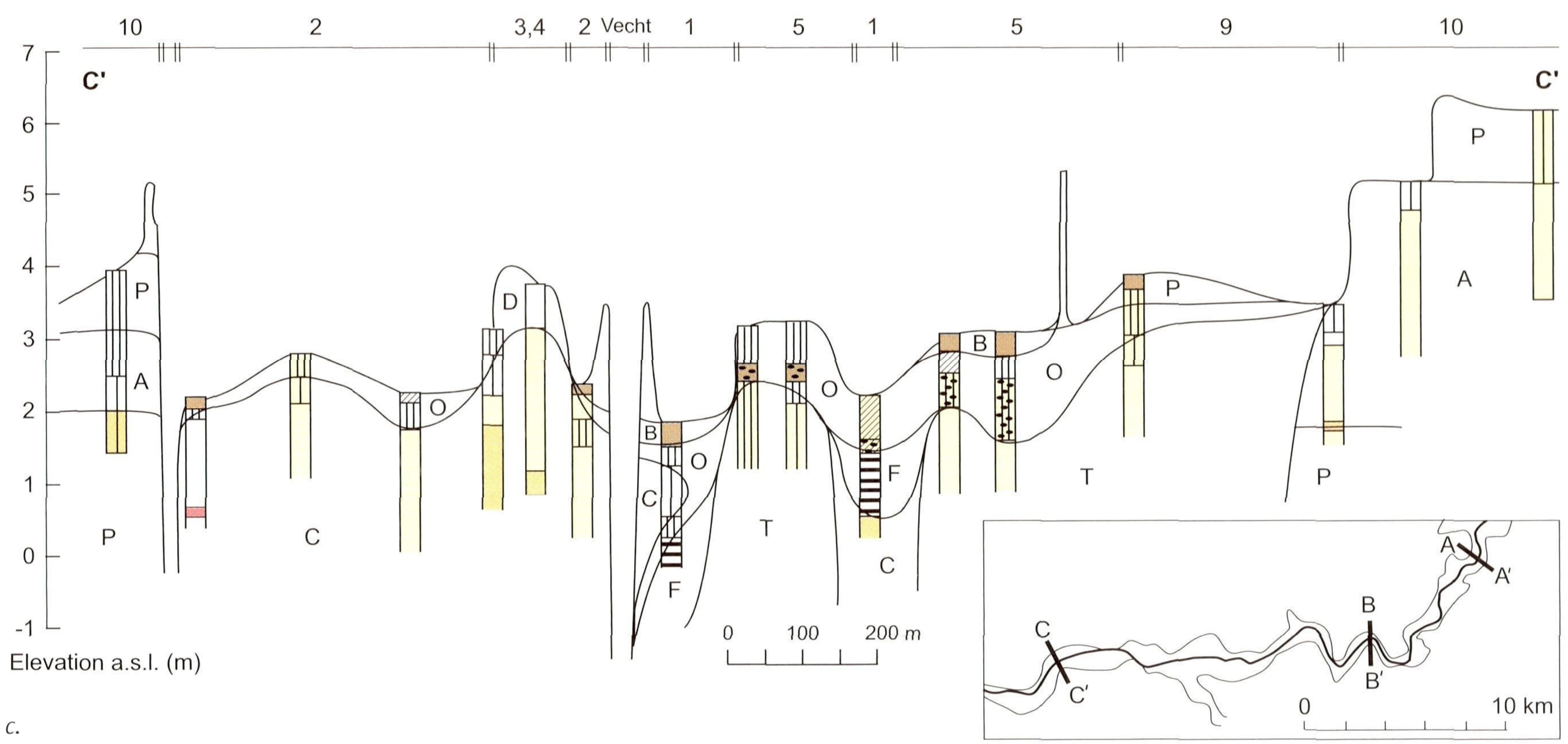

Fig. 6. Cross sections showing alluvial valley topography, borehole sediment characteristics and lithological units of reach $B$ (numbers 0-11 refer to landforms given in Table 2; letters $D, B, O, F, C, A, S$, and $W$ refer to architectural elements mentioned in Table 3; $P=$ plaggen-layer). 
Table 6. Average channel migration rates in historical time.

\begin{tabular}{llll}
\hline Period & Lateral erosion & & \\
\cline { 2 - 4 } & $\begin{array}{l}\text { Area } \\
\text { (ha) }\end{array}$ & $\begin{array}{l}\text { M } \\
\left(\mathrm{m} \mathrm{yr}^{-1}\right)\end{array}$ & $\begin{array}{l}\mathrm{M} / \mathrm{w} \\
\left(\mathrm{yr}^{-1}\right)\end{array}$ \\
\hline $1720-1850$ & 334 & 0.46 & 0.0082 \\
$1850-1890$ & 168 & 0.55 & 0.0099 \\
\hline
\end{tabular}

M: migration rate; $\mathrm{M} / \mathrm{w}$ : relative migration rate; w: channel width

N

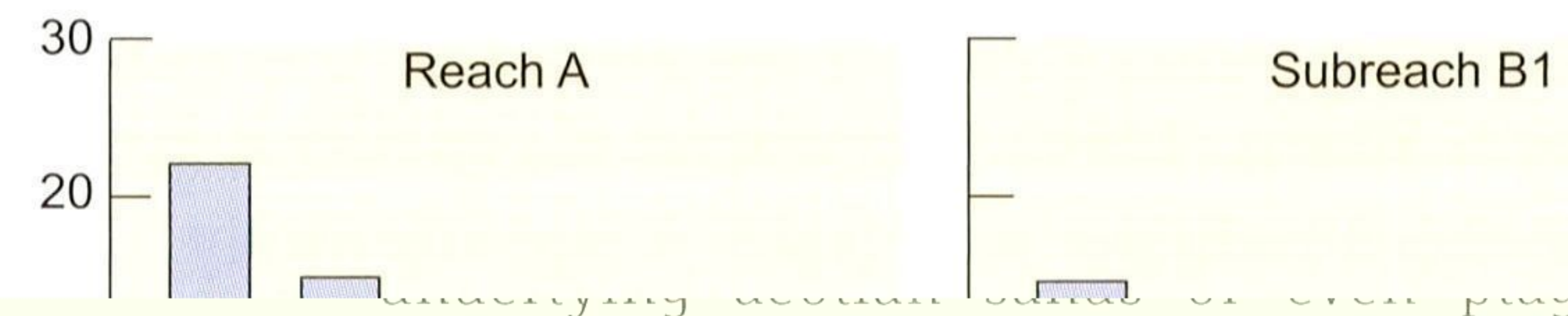

underlying aeolian sands or even plaggen-layers (Fig. 6c). These erodible sands were observed in subreach B4 only.

A typical example of a bend with resistant bank sediments is shown in Fig. 8b. Bends of this type occurred in the reaches $A$ and $B$, where the river impinged upon terrain with a plaggenlayer (Fig. 5 and Fig. 6a). Fields with plaggen-soils were often surrounded by hedges. Due to the binding forces of abundant organics and roots of fringing hedges, river banks in which a plaggen-layer is exposed are stable and resistant to fluvial entrainment of material and hampered channel migration in lateral direction. Where a river encountered such terrain, the bend was (often) diverted into a downstream direction and tightened, followed by a neck-cutoff somewhat upstream.

\section{$\mathrm{M} / \mathrm{w}$ \\ $\left(\mathrm{yr}^{-1}\right)$ \\ 0.0082 \\ 0.0099}

: channel width

Subreach B1

confined by Late Glacial deposits rich in iron and contrast, it was able to lar meander pattern in its reach B4.

bends were observed in bserved during the period ich is a migration rate of ample of such a rapidly depicts schematically the in subreach B2. Bends of vhere the river impinged
These erodible sands were observed in subreach B4 only.

A typical example of a bend with resistant bank sediments is shown in Fig. 8b. Bends of this type occurred in the reaches $A$ and $B$, where the river impinged upon terrain with a plaggenlayer (Fig. 5 and Fig. 6a). Fields with plaggen-soils were often surrounded by hedges. Due to the binding forces of abundant organics and roots of fringing hedges, river banks in which a plaggen-layer is exposed are stable and resistant to fluvial entrainment of material and hampered channel migration in lateral direction. Where a river encountered such terrain, the bend was (often) diverted into a downstream direction and tightened, followed by a neck-cutoff somewhat upstream. Tight river bends are often associated with the formation of concave bank benches and an attack of the convex bank, leading to meander cutoff (Thorne, 1992).

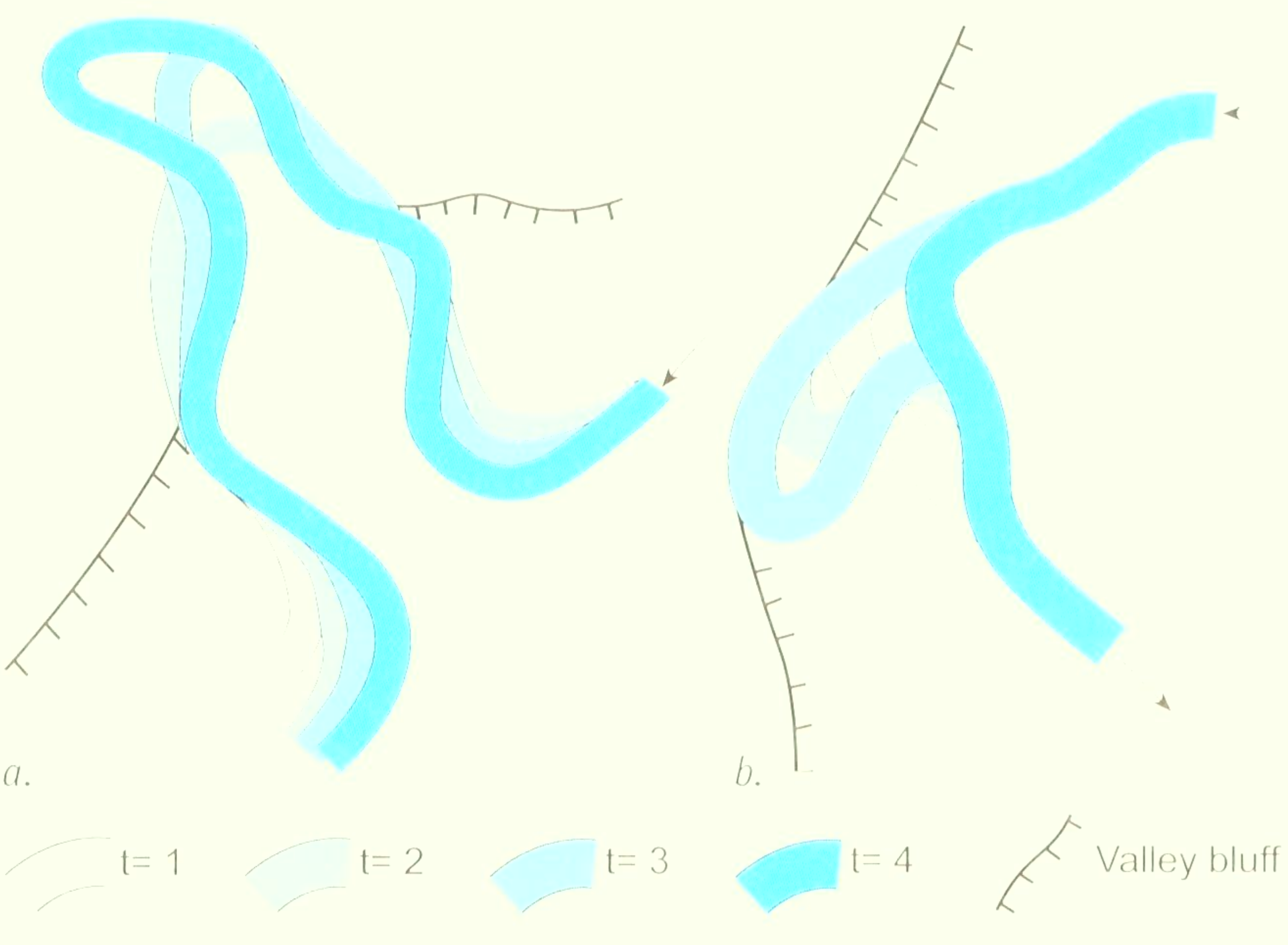

Fig. 8. Styles of meander evolution influenced by banks composition: a. banks dominated by very erodible aeolian sands; and b. banks with resistant plaggen-layers on top.

\section{Discussion}

Significance of bank materials

Classifications of channel pattern have been related to the width-depth ratio (Schumm, 1977; Fredsøe, 1978; Rosgen, 1994). Channels with more cohesive materials tend to be relatively narrow, deep and sinuous, and have smaller wavelengths (Schumm, 1968). Moreover, these channels tend to be more stable. Historical data on the channel width at high discharge and bankfull depth are provided by a study of Staring \& Stieltjes (1848). Mean values of the width-depth ratio per

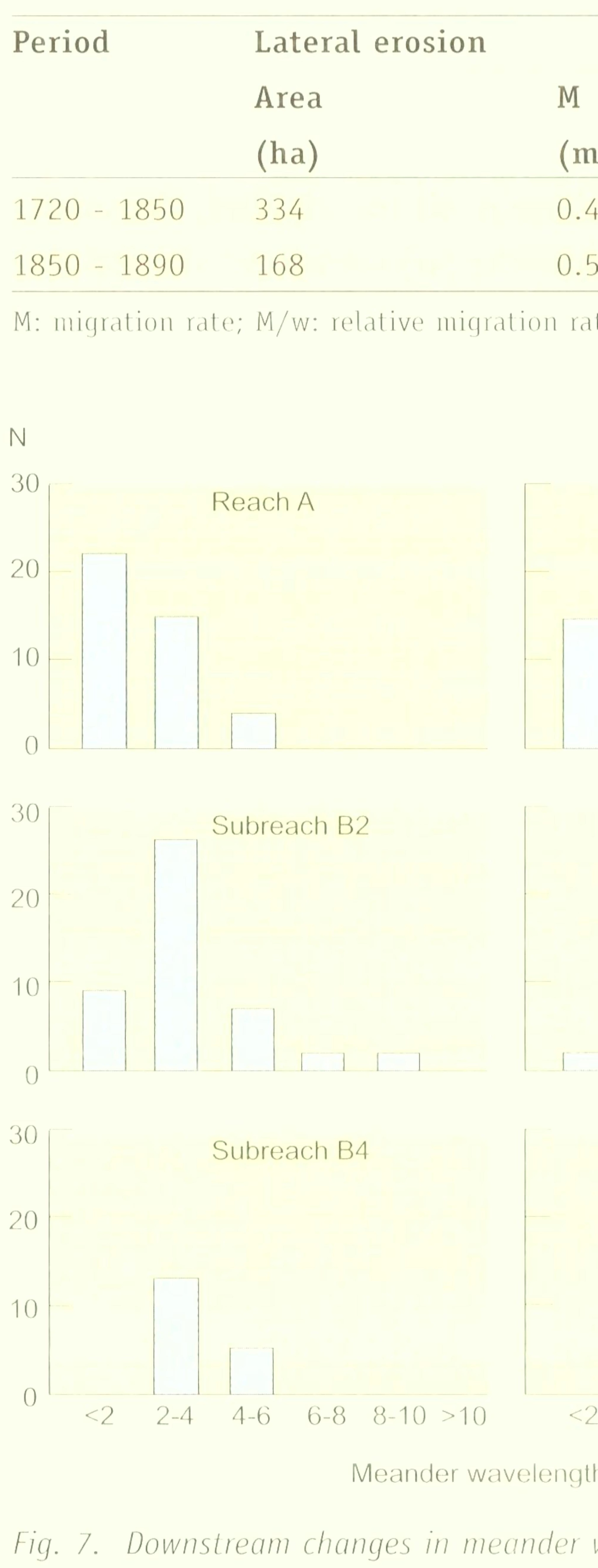

the river. The river was much mort terrace outcrops capped by overban plaggen-layers in subreach B3. In meander freely and to develop a reg wide belt of channel deposits in su

Meander bend migration

Maximum rates of bank retreat reach B. Maximum bend migration 1720 - 1890 amounted to 500 m, $2.94 \mathrm{~m}$ per year. An imaginary migrating bend is given in Fig. 8a. evolution of the large meander bend this type developed at locations 


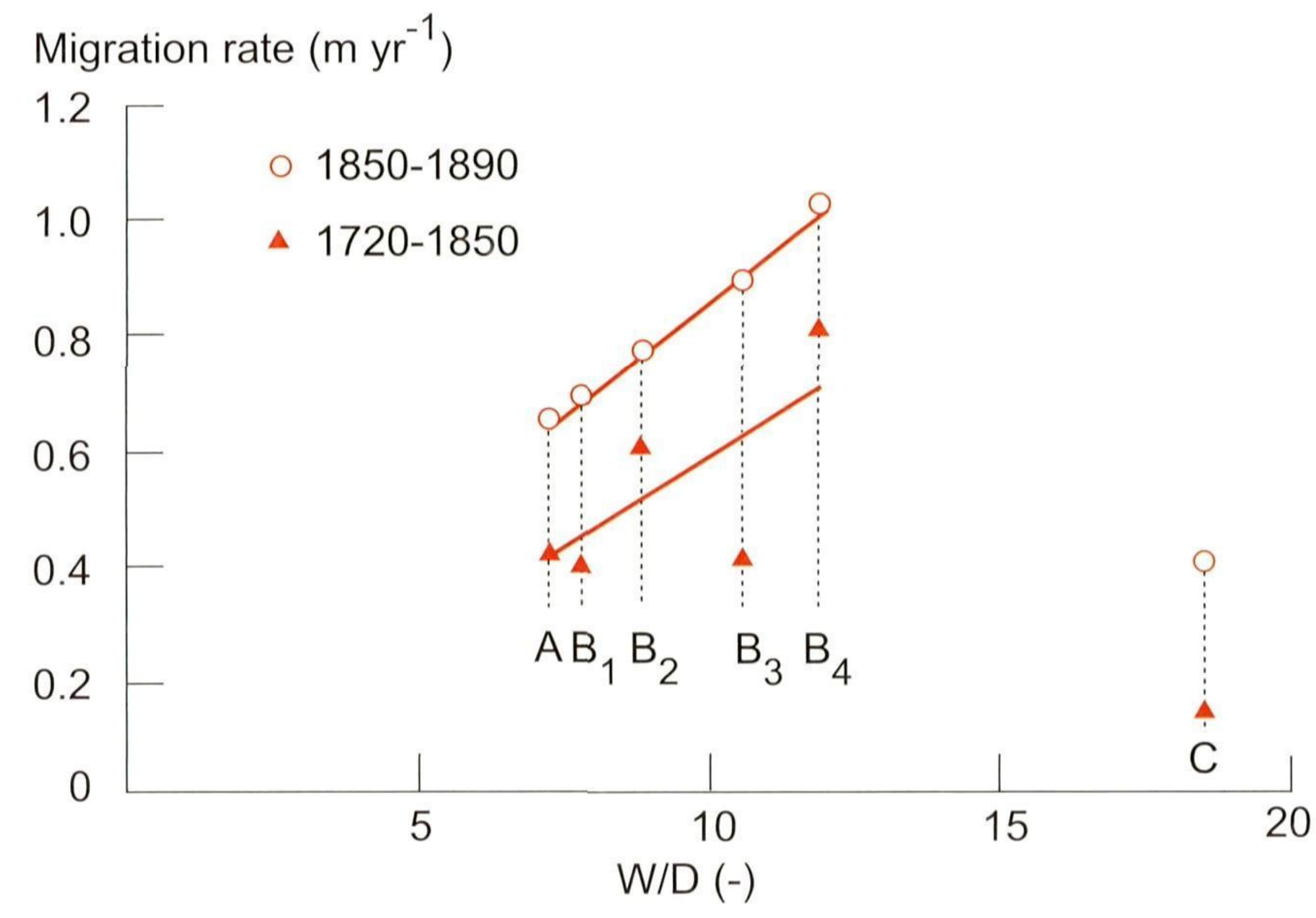

Fig. 9. Relationship between mean channel migration rate and mean width-depth ratio values of river reaches.

way downstream, the migration rates of the river channel increased when going from reach $A$ to reach $B$ because in reach $B$ valley bluffs consisting of sandy material provided sediment to the river. As a result, sandy channel belt sediments increased in extent in downstream direction, which favoured the downstream increase in migration rates within reach $\mathrm{B}$ once more.

In reach $C$, the width-depth ratio values are much higher than those of reach $B$, but migration rates were much lower. Obviously, the relationships described above are not valid here. The high width-depth ratio values are mainly due to a large width of the river channel (Fig. 10). This supports the notion that the presence of dikes is the most likely cause of channel stability. Following embankment, channel migration must have been hampered more and more by dikes, initially leading to downstream migration. As soon as the sinuosity of the channel became out of phase with the alignment of the dikes, migration must have stopped. Along the River Teshio, Ikeda (1989) observed that this was associated with a decrease in channel sinuosity and a widening of the channel. Widening increases the wetted perimeter and is a means to restore the channel's hydraulic roughness.

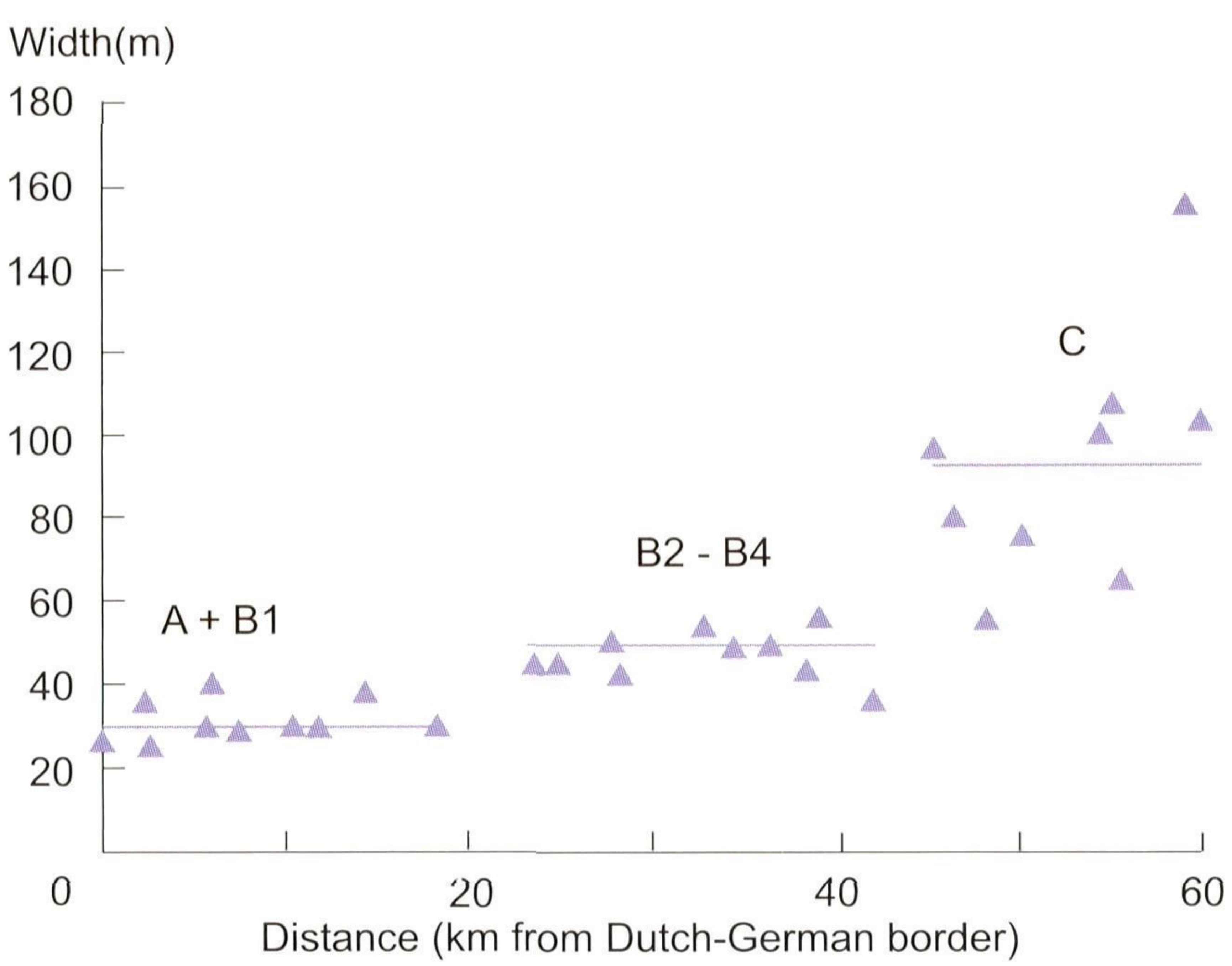

Fig. 10. Channel width in river reaches.

\section{Classification of erodibility}

To take account of the effect of bed and bank materials on channel properties, Schumm $(1968,1977)$ related some of the channel properties to the percentage silt and clay in the sediments forming the perimeter of the channel. Sediments are more cohesive with increasing percentages of silt and clay so that these are considered an indication of bank stability. Silt and clay content of some of the deposits along the River Vecht can be derived from grain-size distributions of soils, described at type localities of soils in this area (Staring Centrum, 1989; Kuijer \& Rosing, 1994). Comparison of deposits is based on data on the C-horizons at a depth of approximately $1 \mathrm{~m}$ (Fig. 11). The data on silt and clay content explain most of the observations on bank stability. Floodbasin deposits and loamy overbank deposits have high values of silt and clay (23-85\%) and thus will be resistant to erosion. The silt and clay content of these deposits decreases in downstream direction, from 85\% in reach $\mathrm{A}$ to $23 \%$ in reach $\mathrm{C}$, suggesting a downstream decrease in cohesion. Overbank deposits overlying Weichselian fluvioperiglacial deposits in reach $B$, however, are rich in iron (Fig. 6) and this contributes to their resistance. Plaggen-soils have intermediate values ranging from $11-15 \%$, which seem to be relatively low as plaggen-layers were assumed to be resistant to erosion. The cohesiveness of plaggen-layers, however, is also related to the higher content of organic matter. Both the aeolian dune deposits $(2-5 \%)$ and the channel deposits (4-11\%) contain very small amounts of silt and clay and will be very erodible.

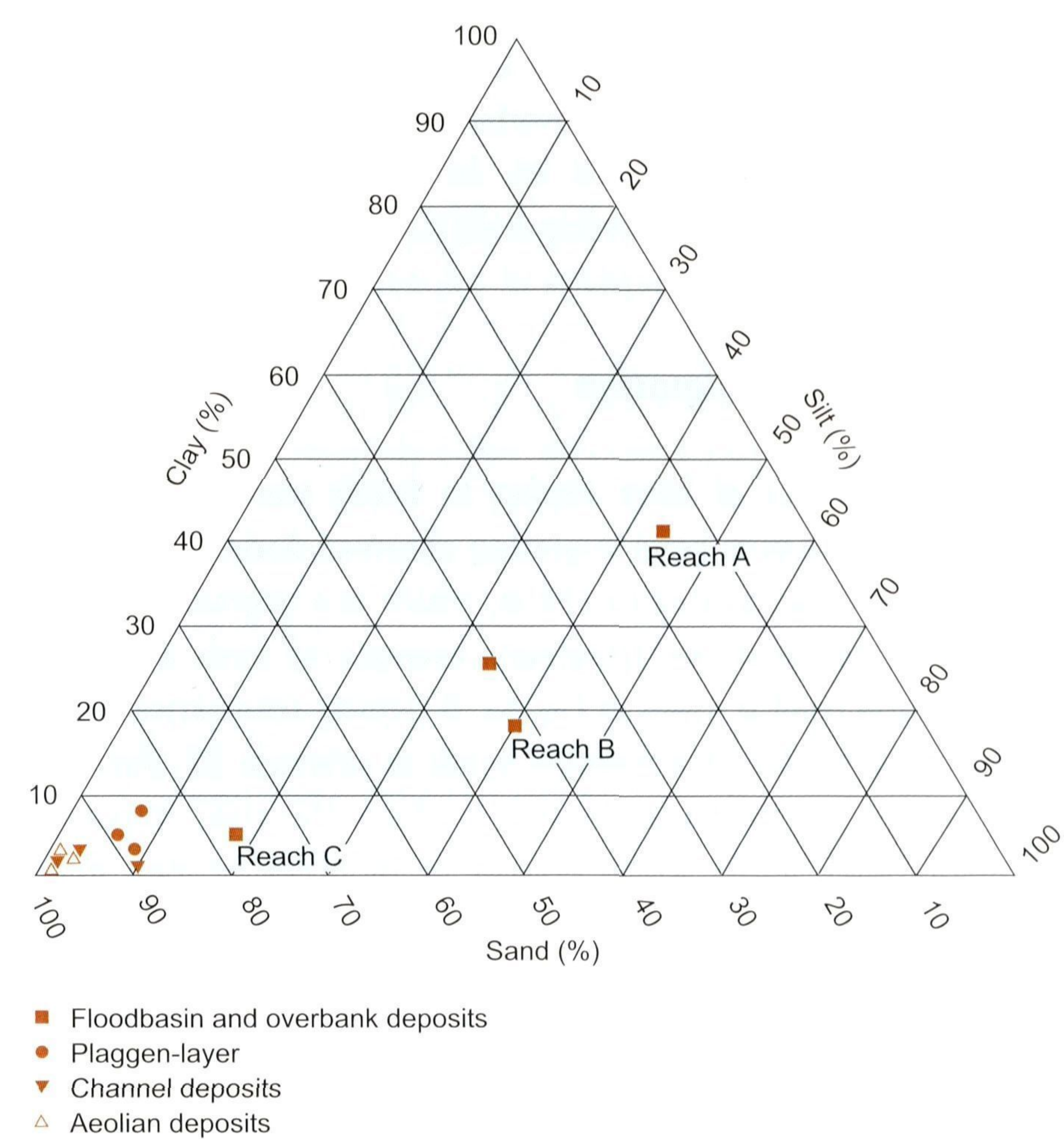

Fig. 11. Textural composition of deposits along the River Vecht. 
Historical evidence on channel migration and the bank material properties are used to set up a ranking in erodibility of river banks. Four classes of erodibility are proposed, related to bank composition:

1. Very erodible are banks dominated by non-cohesive sands characteristic of channel deposits and aeolian dune deposits. These are found in areas with scroll bars and swales, natural levees and aeolian dunes. Banks in which coarse fluvioperiglacial deposits occur at the base are also very erodible. This type of banks was observed in open fields at coversand ridges adjacent to the valley bluffs.

2. Erodible are banks dominated by loamy sands, sometimes rich in iron, with intermediate cohesion. These are typical of overbank deposits and aeolian sand sheet deposits and are related to morphological units mapped as floodplain flats and coversand undulations / river terraces.

3. Resistant are banks with a cohesive plaggen-layer on top of overbank deposits, fluvio-periglacial deposits or aeolian deposits. These are related to open fields.

4. Very resistant to erosion are banks dominated by very cohesive floodbasin deposits. 0ccasionally, floodbasin deposits are underlain by channel fill deposits, which have more or less the same properties. Any role of separate clay plugs (Thorne, 1992, Hudson \& Kesel, 2000) was not observed.

\section{Application in river rehabilitation}

The River Vecht and its floodplain have been designated to be part of the National Ecological Network in the Netherlands (Ministerie van Landbouw, Natuurbeheer en Visserij, 1990; Provincie Overijssel, 1992). The Vecht valley is considered an important corridor for the migration of species between upland stream valleys and lowland marshes along Lake IJssel, but at present the river system lacks habitats crucial to characteristic riverine species. For the selection of areas along the river suitable of meander rehabilitation, a simple model of downstream changes of meandering styles in the lower reaches of the River Vecht was constructed, in which the implications described in this paper were summarised (Fig. 12). Large dynamics are neither expected in reaches $\mathrm{A}$ and $\mathrm{B} 1$ where banks consisting of very resistant floodbasin clays hamper migration, nor in reach $\mathrm{C}$ which is confined by dikes. Conspicuous channel migration and lateral accretion deposits are more likely to be expected in the reaches B2 - B4, due to their valley setting. Within these reaches effects will be smallest in case plaggenlayers are exposed in channel banks, but will be largest in case the river will be allowed impinging again on valley bluffs consisting of aeolian dune deposits. Maximum bend migration there will not be more than ca $3 \mathrm{~m}$ per year on the average, depending on the width-depth ratio implemented.

That the present, straightened river channel is still capable to meander is indicated by data on specific stream power. Whereas values of specific stream power at bankfull discharge varied from 6.8 to $9.8 \mathrm{~W} \mathrm{~m}^{-2}$ in 1890 , the present values range from 4.0 to $6.8 \mathrm{~W} \mathrm{~m}^{-2}$, which is still comparable to those of other high sinuosity meandering rivers (Van den Berg, 1995). Besides, it may be assumed that the present weirs will not entirely hamper the meandering process. Weirs are open during periods of bankfull and higher discharges, which are considered to be the most effective channel forming events (Andrews, 1980; Richards, 1982).

Following this study, removal of revetments and re-connecting oxbow lakes to the river are being considered to rehabilitate the meandering of the river (Werkgroep Vechtvisie, 1997; Duursema, 2004). 0xbow lakes will be connected because

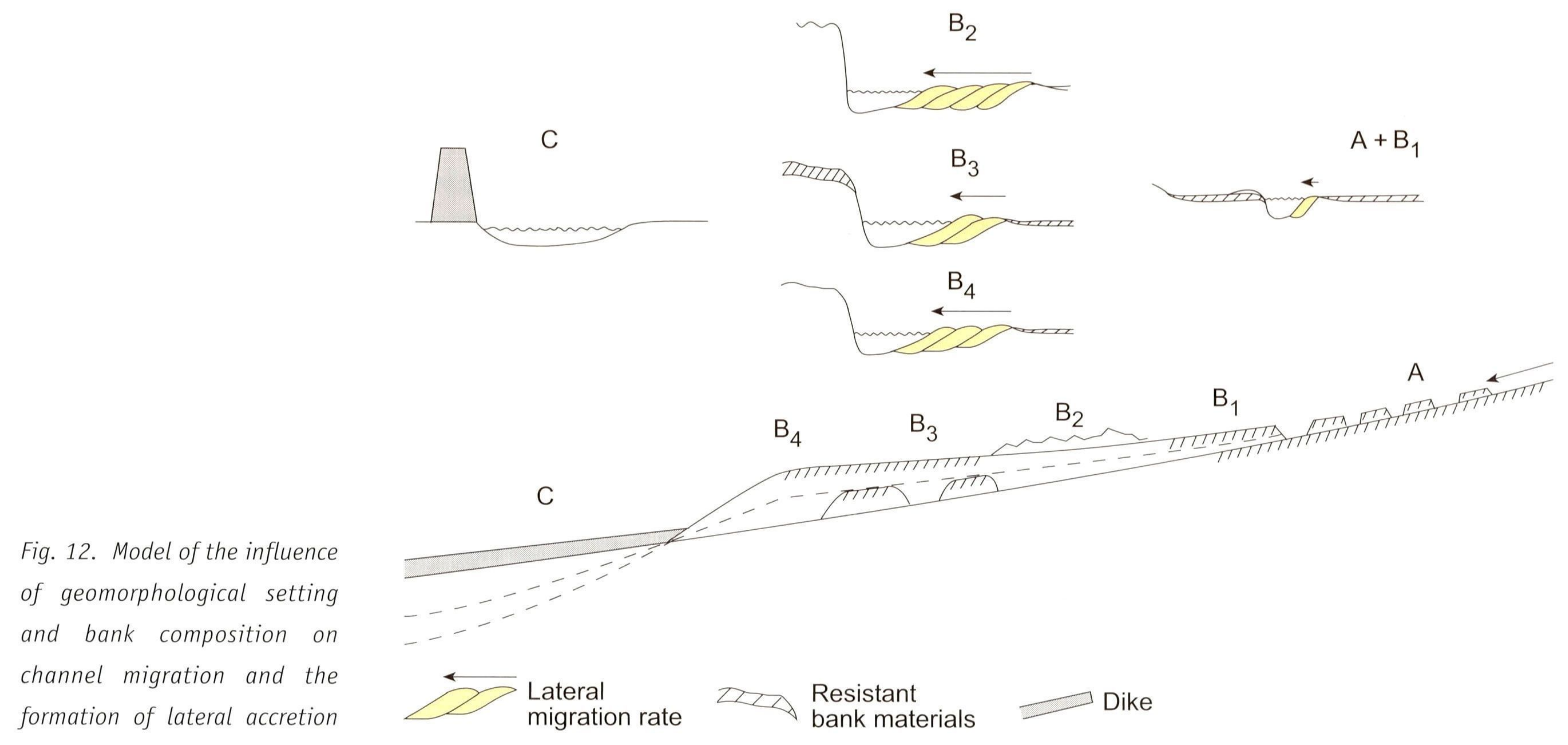

deposits. 
only then the meandering process will have quick results. At present, one new meander has been artificially created in the point-bar area enclosed by the Uilenkamp oxbow lake, just at the beginning of reach B2. In fact this new meander is a copy of the result of a historical neck-cutoff, as depicted in Fig 8b. The historical width-depth ratio, however, was not copied yet, because just one shallow meander would create a bottle-neck in the river. To overcome this problem a scenario is envisaged now, in which the entire river is rehabilitated (Maas et al., 2007).

\section{Conclusions}

Prior to channelization, the lower River Vecht was an example
Fredsøe, J., 1978. Meandering and braiding of rivers. Journal of Fluid Mechanics 84: 609-624.

Glitz, D., 1983. Künstliche Gerinne: die Altarme von Morgen? Garten und Landschaft 83, 2: 109-111.

Hansen, H.O., Boon, P.J., Madsen, B.L. \& Iversen, T.M. (eds), 1998. River restoration: the physical dimension. Aquatic Conservation: Marine and Freshwater Ecosystems 8: 1-264.

Hooke, J.M. \& Redmond, C.E., 1989. Use of carthographic sources for analysing river channel change with examples from Britain. In: Petts, G.E., Möller, H. \& Roux, R.L. (eds): Historical change of large alluvial rivers: western Europe. John Wiley \& Sons (Chichester): 79-93.

Howard, A.D., 1992. Modeling channel migration and floodplain sedimentation in meandering streams. In: Carling, P.A. \& Petts, G.E. (eds): Lowland floodplain rivers: geomorphological perspectives. John Wiley \& Sons (Chichester): 1-41. of a river with a dorinctraam succeccinn of different

for optimising the understanding and prediction of the influence of bank materials on channel pattern.

These implications of meander variability can also be used to assess the effects of the rehabilitation of the meandering process. This type of geomorphological-sedimentological studies is therefore recommended for use in river rehabilitation planning.

\section{References}

Andrews, E.D., 1980. Effective and bankfull discharges of streams in the Yampa River basin, Colorado and Wyoming. Journal of Hydrology 46: 311-330.

Berendsen, H.J.A., 1982. De genese van het landschap in het zuiden van de provincie Utrecht: een fysisch-geografische studie. Utrechtse Geografische Studies 25, Rijksuniversiteit Utrecht, Geografisch Instituut (Utrecht): 256 pp.

Brookes, A., 1987. Restoring the sinuosity of artificially straightened stream channels. Environmental Geology and Water Sciences 10: 33-41.

Brookes, A. \& Shields, F.D. Jr. (eds), 1996. River channel restoration: guiding principles for sustainable projects. John Wiley \& Sons (Chichester): $433 \mathrm{pp}$.

Bull, W.B., 1991. Geomorphic responses to climatic change. Oxford University Press (New York): 326 pp.

Detering, U., 2000. Das Gewässerauenprogramm NRW am Beispiel der Oberen Lippe. In: Bundesamt für Naturschutz (eds): Renaturierung von Bächen, Flüssen und Strömen. Angewandte Landschaftsökologie 37: 153-162.

Duursema, G., 2004. Leidraad voor herstel van de Overijsselse Vecht. Waterschap Velt en Vecht (Coevorden): $64 \mathrm{pp}$.

Ente, P., Haans, J.C.F.M. \& Knibbe, M., 1965. De bodem van Overijssel, de Noordoostpolder en Oostelijk Flevoland. Stichting voor Bodemkartering (Wageningen): $104 \mathrm{pp}$.

\section{Hudcon $P \&$ Kos
(Washington, D.C): 51-68.}

Knighton, D., 1984. Fluvial forms and processes. Edward Arnold (London): 218 pp. Kolb, C.R., 1963. Sediments forming the bed and banks of the lower Mississippi River and their effect on river migration. Sedimentology 2: 227-234.

Kuijer, P.C. \& Rosing, H., 1994. Bodemkaart van Nederland 1: 50 000: toelichting bij kaartblad 21 0ost Zwolle. DLO-Staring Centrum (Wageningen): 175 pp.

Leopold, L.B. \& Wolman, M.G., 1957. River channel patterns: braided, meandering and straight. Geological Survey, Professional Paper 282-B, United States Department of the Interior (Washington D.C.): $42 \mathrm{pp}$.

Leopold, L.B., Wolman, M.G. \& Miller, J.P., 1964. Fluvial processes in geomorphology. Freeman (San Francisco): 522 pp.

Maas, G., Corporaal, A., Kranendonk, R. \& Wolfert, H., 2007. Ruimte voor kleine rivieren: Overijsselse Vecht op koers? Rapport 1512, Alterra (Wageningen): $36 \mathrm{pp}$.

Meinardi, C.R., Schotten, C.G.J. \& De Vries, J.J., 1998. Grondwateraanvulling en oppervlakkige afstroming in Nederland: langjaarlijkse gemiddelden voor de zand- en leemgebieden. Stromingen 4: 27-41.

Miall, A.D., 1985. Architectural-element analysis: a new method of facies analysis applied to fluvial deposits. Earth-Science Reviews 22: 261-308.

Middelkoop, H., 1997. Embanked floodplains in the Netherlands: geomorphological evolution over various time scales. Netherlands Geographical Studies 224, Koninklijk Nederlands Aardrijkskundig Genootschap / Universiteit Utrecht, Faculteit Ruimtelijke Wetenschappen (Utrecht): 341 pp.

Ministerie van Landbouw, Natuurbeheer en Visserij, 1990. Natuurbeleidsplan: regeringsbeslissing. Sdu uitgeverij (Den Haag): 272 pp.

Nanson, G.C. \& Croke, J.C., 1992. A genetic classification of floodplains. Geomorphology 4: 459-486.

Page, K. \& Nanson, G., 1982. Concave-bank benches and associated floodplain formation. Earth Surface Processes and Landforms 7: 529-544.

Pape, J.C., 1970. Plaggen soils in the Netherlands. Geoderma 4: 229-255. 
Parker, G., 1998. River meanders in a tray. Nature 395: 111-112.

Provincie Overijssel, 1992. Beleidsplan natuur en landschap Overijssel 19921998. Provincie Overijssel (Zwolle): 88 pp.

Rasmussen, J.B., 1999. The Skjern River restoration project: Denmark's largest nature restoration project. Danish Ministry of the Environment and Energy / National Forest and Nature Agency (Copenhagen): 32 pp.

Reineck, H.-E. \& Singh, I.B., 1980. Depositional Sedimentary Environments: With Reference to Terrigeneous Clastics, second, revised and updated edition. Springer-Verlag (Berlin): $439 \mathrm{pp}$.

Richards, K.S., 1982. Rivers: form and process in alluvial channels. Methuen (London): $358 \mathrm{pp}$.

Rosgen, D.L., 1994. A classification of natural rivers. Catena 22: 169-199.

Schumm, S.A., 1968. River adjustment to altered hydrologic regimen: Murrumbidgee River and palaeochannels, Australia. US Geological Survey, Professional Paper 598 (Washington D.C.): 65 pp.

Schumm, S.A., 1977. The fluvial system. John Wiley \& Sons (New York): 338 pp.

Staring, W. \& Stieltjes, T.J., 1848. De Overijsselsche wateren. s.n. (Zwolle): $488 \mathrm{pp}$.

Staring Centrum, 1989. Bodemkaart van Nederland $1: 50$ 000: toelichting bij de kaartbladen 22 West Coevorden en 22 0ost Coevorden. Staring Centrum (Wageningen): $171 \mathrm{pp}$.

Ten Cate, J.A.M., Van Holst, A.F., Kleijer, H. \& Stolp, J. Handleiding bodemgeografisch onderzoek: richtlijnen en voorschriften. Deel A: Bodem. Technisch Document 19A, DLO-Staring Centrum (Wageningen): 222 pp.

Thorne, C.R., 1992. Bend scour and bank erosion on the meandering Red River, Louisiana. In: Carling, P.A. \& Petts, G.E. (eds): Lowland floodplain rivers: geomorphological perspectives. Wiley (Chichester): 95-115.

Van de Kraats, J.A. (ed.), 1994. Rehabilitation of the River Rhine: proceedings of the International Conference on Rehabilitation of the River Rhine, 15-19 March 1993, Arnhem, the Netherlands. Water Science and Technology 29, 3: $1-394$.

Van den Berg, J.H., 1995. Prediction of alluvial channel pattern of perennial rivers. Geomorphology 12: 259-279.

Vivash, R., Ottosen, O., Janes, M. \& Sørensen, H.V., 1998. Rehabilitation of the rivers Brede, Cole and Skerne: a joint Danish and British EU-LIFE demonstration project, II - The river rehabilitation works and other related practical aspects. Aquatic Conservation: Marine and Freshwater Ecosystems 8: 197-208.

Werkgroep Vechtvisie, 1997. De Vechtvisie: stap voor stap naar een duurzame Vecht. Arcadis Heidemij Advies (Deventer): 113 pp.

Westerhoff, W.E., Wong, T.E. \& De Mulder, E.F.J., 2003. Opbouw van de ondergrond. In: De Mulder, E.F.J., Geluk, M.C., Ritsema, I.L., Westerhof, W.E. \& Wong, T.E.: De ondergrond van Nederland. Wolters-Noordhoff (Groningen): 247-352.

Wolfert, H.P., 2001. Geomorphological Change and River Rehabilitation: Case Studies on Lowland Fluvial Systems in the Netherlands. PhD Thesis. Scientific Publications 6, Alterra Green World Research (Wageningen): 200 pp.

Wolfert, H.P., Maas, G.J. \& Dirkx, G.H.P., 1996. Het meandergedrag van de Overijsselse Vecht: historische morfodynamiek en kansrijkdom voor natuurontwikkeling. Rapport 408, DL0-Staring Centrum (Wageningen): 98 pp. 